\title{
A Dynamic History
}

\section{ms Sinai, Arabic 151 in the Hands of Scribes, Readers, and Restorers}

\author{
Vevian F. Zaki \\ History Faculty, University of Oxford, Oxford, United Kingdom \\ vevianfarok@gmail.com
}

\begin{abstract}
This paper unfolds parts of the dynamic, yet mostly hidden, history of Ms Sinai Arabic 151 based on its paleographical, codicological, paratextual, and textual features. Combining these aspects opens new horizons of research in the Arabic Bible manuscripts that had previously received attention limited solely to the text. Ms Sinai, Ar. 151 is an intact manuscript containing the Pauline Epistles, Acts of the Apostles, and the Catholic Epistles. Its fame derives mainly from its colophon, which dates it to $867 \mathrm{CE}$, and bestows it with the distinction of belonging to the earliest Arabic Bibles. In observing the various stages through which the manuscript evolved from two separate units of production into the codex preserved today, several aspects of the life of Ms Sinai, Ar. 151, such as the copies made from it, its damage and restoration, and the functions it served, become clearer. Furthermore, for different reasons, scholars have cast shadows on its colophon's authenticity. Our investigation clarifies that there is no reason to suspect the authenticity of the colophon.
\end{abstract}

\section{Keywords}

Arabic Bible - Christian-Arabic manuscripts - Pauline Epistles - New Testament Sinai manuscripts - St Catherine's Monastery 


\section{Introduction $^{1}$}

The Christian communities of the Near East gradually abandoned their original languages-Greek, Syriac, or Coptic - and adopted the Arabic language after the rise of Islam. Although these former languages continued to be used in liturgy, they became incomprehensible for use in daily life and in literary production. Manuscript evidence suggests that apologetic writings were the first to emerge in the Arabicized Christian communities. The treatise of Ms Sinai, Ar. 154, edited under the title On the Triune Nature of God, and dated to $778 \mathrm{CE}$, and summa theologiae of MS London, BL, Or. 4950, dated to 877, are anonymous examples. ${ }^{2}$ Another example is the several treatises by Theodore Abu Qurra (755-810), the bishop of Harrān. ${ }^{3}$ Arabic-speaking Christians quoted Biblical verses in Arabic, employing them in apologetic works to argue for the Christian doctrines that were no longer accepted in their new Islamic milieu. The manuscripts of whole books of the Bible translated into Arabic compose another case. The earliest manuscripts go back no further than the late 8th century, for instance, MS Sinai, Ar. 154, which includes in addition to the aforementioned treatise the Acts of the Apostles and the Catholic Epistles. Other manuscripts date to the ninth century based on paleographical features or colophons. MS Sinai, Ar. 155 and its membrum disjectum MS London, BL, Or. 8612 belong to the first category, and the manuscript in hand for this paper, Sinai, Ar. ${ }_{151}$, falls into the latter category with its $867 \mathrm{CE}$ colophon. ${ }^{4}$

1 Submitted in an earlier version on January 31, 2018. Accepted for publication on January 21, 2020.

2 See Margaret Dunlop Gibson, ed., An Arabic Version of the Acts of the Apostles and the Seven Catholic Epistles from an Eighth or Ninth Century Ms. in the Convent of St Catherine on Mount Sinai, with a Treatise on the Triune Nature of God, with Translation, from the Same Codex, Studia Sinaitica 7 (London: C.J. Clay and Sons, 1899); and Sidney H. Griffith, "Greek into Arabic: Life and Letters in the Monasteries of Palestine in the Ninth Century: The Example of the 'Summa Theologiae Arabica," Byzantion $5^{6}$ (1986): 117-138; See the argument on the Calendar used in and the redating of these works in Mark N. Swanson, "Some Considerations for the Dating of Fī Tațlīt Allāh al-Wāḥid (Sin. Ar. 154) and al-Ǧāmic Wuğūh al-Īmān (London, British Library Or. 4950)," Parole de l'Orient 18 (1993): 115-141.

3 John C. Lamoreaux, "The Biography of Theodore Abū Qurrah Revisited," Dumbarton Oaks Papers 56 (2002): 25-40; John C. Lamoreaux, "Theodore Abū Qurra," in Christian-Muslim Relations: A Bibliographical History, ed. David Thomas and Barbara Roggema, vol. I, 6oo-90o (Leiden: Brill, 2009), 253-255.

4 See the edition of ms Sinai, Ar. 155 in Margaret Dunlop Gibson, ed., An Arabic Version of the Epistles of St Paul to the Romans, Corinthians, Galatians, with Part of the Epistle to the Ephesians from a Ninth Century Ms. in the Convent of St Catharine on Mount Sinai, Studia Sinaitica 2 (London: C.J. Clay and Sons, 1894). 
In the last decade, scholarship on the Arabic Bible unearthed unprecedented numbers of manuscripts. ${ }^{5}$ The texts of these manuscripts have received increased attention from scholars. ${ }^{6}$ They investigate these biblical documents to determine their Vorlagen, i.e. source texts, and the techniques utilized in their translation. In doing so, they attempt to build as much of the text's history as possible by noting the unique strategies and fingerprints left by each scribe. ${ }^{7}$ However, the history of the Arabic Bible as a book still requires more scholarly attention. The process of making the physical volumes as well as their circulation is still vague. What we have access to is a description made by a few translators of the translation process, detailing the Vorlagen they depended on, their motives for performing the translation, their method of text selection, and their translation strategies. Except for al-Ḥārith ibn Sinān's preface to the Pentateuch in the tenth century, these translation process descriptions appear to be from the thirteenth century onwards and particularly from the Coptic community. ${ }^{8}$ For instance, Coptic scholar Hibat Allāh ibn al-'Assāl's introduction to his recension of the four gospels $\left(125^{2} \mathrm{CE}\right)$ informs the reader of his motives and translation techniques. ${ }^{9}$ In the same century, Yūḥannā al-Qalyūbī penned an

5 In his survey Ronny Vollandt estimated the total number of manuscripts as ten thousand. See Ronny Vollandt, "The Status Quaestionis of Research on the Arabic Bible," in Studies in Semitic Linguistics and Manuscripts: A Liber Discipulorum in Honour of Professor Geoffrey Khan, ed. Nadia Vidro et al., Studia Semitica Upsaliensia 30 (Uppsala: Uppsala Universite, 2018), 442462,442 .

6 Kashouh undertook a study on the Arabic Gospels, categorizing their texts into families and determining the Vorlage of each family. See Hikmat Kashouh, The Arabic Versions of the Gospels: The Manuscripts and Their Families (Berlin: De Gruyter, 2011); Vollandt worked on the Pentateuch with a focus on two early versions, studying the translation strategies they exhibit. See Ronny Vollandt, Arabic Versions of the Pentateuch: A Comparative Study of Jewish, Christian, and Muslim Sources, Biblia Arabica 2 (Leiden: Brill, 2015); Hjälm studied the Arabic translations of the book of Daniel until the thirteenth century, focusing on the translation techniques in two of them. See Miriam L. Hjälm, Christian Arabic Versions of Daniel: A Comparative Study of Early Mss and Translation Techniques in Mss Sinai Ar. 1 and 2, Biblia Arabica 4 (Leiden: Brill, 2016).

7 For a survey of the state of research in the field, see Nathan Gibson et al., "The Bible in Arabic: An Update on the State of Research," in Between the Cross and the Crescent: Studies in Honor of Samir Khalil Samir, S.J. on the Occasion of His Eightieth Birthday, ed. Željko Paša (Rome: Pontificium Institutum Studiorum Orientalium, 2018), 57-84. For a bibliography of the field, see Ronny Vollandt and Nathan Gibson, eds, Bibliography of the Arabic Bible: A Classified and Annotated History of Scholarship (Munich: Biblia-Arabica.com, 2017), http:// biblia-arabica.com/bibl.

8 Vollandt, Arabic Versions of the Pentateuch, 6o-63; Griffith, The Bible in Arabic, 136.

9 Awad Wadi, "Al-As'ad Ibn al-'Assāl, Introduzioni alla traduzione dei quattro Vangeli," Studia Orientalia Christiana Collectanea 39 (2006): 47-120. 
introduction to his translation of the Arabic Pauline Epistles (1271 CE). ${ }^{10}$ Moreover, an anonymous author in the thirteenth century made a preface to the translation of Saadiah Gaon that is called the tafsir 'commentary.'11

These prefaces were text-centred and contained nothing about the making of the physical object; thus, the Arabic Bible manuscripts still lack the proper investigation of this aspect. The series of actions involved in a single manuscript's life signify many aspects of the Arabic Bible: the function this manuscript served; the denominations it related to; the copies made from it; the damage it might have encountered during circulation; its restoration; and the other texts used to correct or fill in its missing parts are just a few examples. ${ }^{12}$ The lack of description of these actions invites scholars to rely on the manuscripts themselves, both on their texts and other manuscript witnesses, ${ }^{13}$ and on additional features such as their paleographical, codicological, and para-textual traits. This vagueness increases in the early stages of Arabic Bible manuscripts (ninth-eleventh centuries) that primarily emerged in the Melkite or Greek-Orthodox Church milieu. ${ }^{14}$ However, some attempts have

10 The introduction of al-Qalyūbī has not yet been studied or edited, and the earliest manuscript where it is attested is Ms Vatican, Ar. 28.

11 Vollandt has recently suggested that this anonymous author is actually Hibat Allāh ibn al-'Assāl. See Ronny Vollandt, "The Conundrum of Scriptural Plurality: The Arabic Bible, Polyglots, and Medieval Predecessors of Biblical Criticism," in The Text of the Hebrew Bible and Its Editions: Studies in Celebration of the Fifth Centennial of the Complutensian Polyglot, ed. Andrés Piquer Otero and Pablo A. Torijano Morales, vol. I, Supplements to the Textual History of the Bible (Leiden: Brill, 2016), 75-76; Ronny Vollandt, "Flawed Biblical Translations into Arabic: A Copt and a Jew Study Saadiah's Tafsīr," in Heirs of the Apostles: Studies on Arabic Christianity in Honor of Sidney H. Griffith. Leiden: Brill, 2019, 86.

12 The study of Arabic Islamic manuscripts has made a great advance. See François Déroche, Islamic Codicology: An Introduction to the Study of Manuscripts in Arabic Script, Corr. ed. (London: Al-Furqān Islamic Heritage Foundation, 2005); Adam Gacek, The Arabic Manuscript Tradition: A Glossary of Technical Terms and Bibliography; Supplement (Leiden: Brill, 2008); and Robert M. Kerr and Thomas Milo, eds, Writings and Writing from Another World and Another Era: Investigations in Islamic Text and Script in Honour of Dr Januarius Justus Witkam, Professor of Codicology and Paleography of the Islamic World at Leyden University (Cambridge: Archetype, 2014); Hjälm is currently undertaking a study on the Paleography of the Arabic Christian manuscripts (ninth-tenth centuries). See Miriam L. Hjälm, "Paleographical Typology of Early Christian Arabic Scripts (ca. 9th c.)," in Textual History of the Bible, ed. Armin Lange, III (Leiden: Brill, forthcoming).

13 In this paper, I use "manuscript witnesses" to indicate any copies of a certain text into several manuscripts.

14 Griffith wrote extensively on the Arabicization of the Melkites and the translation movement in the monasteries of Palestine. See for example, Sidney H. Griffith, "The Monks of Palestine and the Growth of Chrisitan Literature in Arabic," Muslim World 78 (1988): 1-28; Sidney H. Griffith, "From Aramaic to Arabic: The Languages of the Monasteries of Palestine in the Byzantine and Early Islamic Periods," Dumbarton Oaks Papers 51 (1997): 11-31; 
constructed the work of some scribes such as Dāwìd al-'Asqalānī (David of Ashkelon) who worked in the beginning of the tenth century and transcribed many manuscripts. ${ }^{15}$ Others focused on the different aspects of the colophons in early Christian-Arabic manuscripts, investigating the dating and numeral systems employed in them. ${ }^{16}$ In later periods, it was possible to build a whole Coptic-manuscript workshop (1584-1590) where several biblical manuscripts were produced. ${ }^{17}$ These works fill part of the scholarly lacuna on the ChristianArabic manuscript culture. Nevertheless, there are more investigations to do in order to reconstruct the life story of certain manuscripts combining all these aspects.

Some manuscripts, more than others, serve as a proper medium for revealing their own life histories; MS Sinai, Ar. 151 ( $\left.\mathrm{S}_{151}\right)$ is one such manuscript. Traces left by scribes, readers, and restorers bespeak its former life. ${ }^{18}$ This article unfolds part of this life by examining S151 and three of its later witnesses: MSs Sinai Ar. NF, parch. MG2 (tenth century); Berlin, Staatsbibliothek zu Berlin, Diez A Oct. 162 (1264 CE); and Florence, Biblioteca Medicea Laurenziana, Conv. Soppr.

and Sidney H. Griffith, "The Gospel in Arabic: An Inquiry into Its Appearance in the First Abbasid Century," Oriens Christianus 69 (1985): 126-167.

15 One of the manuscripts that he transcribed is Ms Sinai, Ar. 73, which contains the Pauline Epistles in Arabic. For more on this manuscript, see Vevian Zaki, "The Textual History of the Arabic Pauline Epistles: One Version, Three Recensions, Six Manuscripts," in Senses of Scripture, Treasures of Tradition: The Bible in Arabic among Jews, Christians and Muslims, ed. Miriam L. Hjälm, Biblia Arabica 5 (Leiden: Brill, 2017), 392-424; For more on his other manuscripts and dating, see André Binggeli, "Les trois David, copistes arabes de Palestine aux 9e-1oe," in Manuscripta Graeca et Orientalia mélanges monastiques et patristiques en l'honneur de Paul Géhin, ed. Anne Boud' hors, André Binggeli, and Matthieu Cassin, Orientalia Lovaniensia Analecta 243 (Leuven: Peeters, 2016), 106-113.

16 Examples include: Serge Frantsouzoff, "Les chiffres coptes dans les manuscrits arabes, chrétiens et musulmans," Parole de l'Orient 39 (2014): 259-273; M. Kawatoko, "On the Use of Coptic Numerals in Egypt in the 16th Century," Orient 28 (1992): 58-74; H. Messiha and Anne Boud' hors, "Les Chiffres Coptes," Le Monde Copte 24 (1994): 25-28; Dmitry A. Morozov, "Aleksandrijsaja Èra v Lavre Sv. Savvy Osviash'ennogo [The Alexandrian Era at Mar Saba]," Kapterevskie Chtenija 11 (2013): 69-71; and Dmitry A. Morozov, "K Datirovke Drevnejshej Arabskoj Rukopisi Evangelija [On the Dating of the Earliest Arabic Gospel Manuscript]," Kapterevskie Chtenija: Sbornik Statej 6 (2008): 19-23.

17 Ronny Vollandt, "From the Desks of a Coptic-Muslim Workshop: Paris, BnF, MS Ar. 1 and the Large-Scale Production of Luxurious Arabic Bibles in Early Ottoman Cairo," in Patronage, Production, and Transmission of Texts in Medieval and Early Modern Jewish Cultures, ed. Esperana Alfonso and Jonathan Decter (Turnhout: Brepols, 2014), 231-265; Ronny Vollandt, "Making Quires Speak: An Analysis of Arabic Multi-Block Bibles and the Quest for a Canon," Intellectual History of the Islamicate World 4, no. 1-2 (2016): 170-209.

18 Aziz Suryal Atiya, Catalogue Raisonné of the Mount Sinai Arabic Manuscripts: Complete Analytical Listing of the Arabic Collection Preserved in the Monastery of St. Catherine on Mt. Sinai, trans. Joseph N. Youssef (Alexandria: Dār al-Macāiif, 1970), 284-287. 
TABLE 1 Scribes and readers who used S151

\begin{tabular}{lll} 
Scribe/reader & Contribution & Date \\
\hline$S^{1}$ (Ibn al-Sirrī?) & $\begin{array}{l}\text { Most of the Pauline Corpus, Acts of the } \\
\text { Apostles, and the Catholic Epistles }\end{array}$ & $867 \mathrm{CE}$ \\
$S^{2}$ (al-Yabrūdī) & Comments and variant readings & $1022-1025 \mathrm{CE}$ \\
$S^{3}$ & Substitution of the lost folios & 12 th? \\
$S^{4}$ & Greek Liturgical Rubrics & Unknown date \\
$S^{5}$ & Arabic Liturgical Rubrics & 11th/12th? \\
$S^{6}$ & Prayer & 12 th \\
$S^{8}$ & comments and variant readings & Unknown date \\
$S^{7}$ (Wahbat Allāh & Reading Note & 1870 \\
Șarrūf) Șarrūf & & \\
\hline
\end{tabular}

$53^{2}$ (late thirteenth century). This examination integrates a textual, para-textual, paleographical, and codicological approach. The aim is to draw together, evidence permitting, different pieces of the various stages that Sinai, Ar. ${ }^{151}$ completed. Tracing this history also contributes to the debate that has arisen regarding its colophon. This article emphasizes this colophon's authenticity, and, in turn, its early date. Following the introduction, the paper narrates the three stages of S151's life: the new manuscript; the defective manuscript; and the restored manuscript. To give an idea of how rich the history of $S_{151}$ is, consider Table 1, which indicates the scribes/readers who intervened in its history.

It is possible to start the story backwards, i.e. as an investigation from the manuscript's current state, explaining each discovery in it. But in order to make the account easier for the reader to follow, I have structured the investigation chronologically, reconstructing S151's life in order, at every step providing evidence based on what we have or do not have in S151. Nevertheless, it should be noted that this is a limited reading of the available data, and future investigation would add even more to this story. Although, initially, a few things seem vague, the different pieces slowly come together to form a virtual life of S151. The paper focuses on the portion containing the Pauline Epistles. All investigations of the manuscripts of this paper are performed on specific "text passages" from each epistle of the Pauline Corpus. ${ }^{19}$

19 The text passages are: 1 Corinthians 7:1-20; 2 Corinthians 6:11-7:1; Galatians3:15-29; Eph- 
As a famous manuscript, $\mathrm{S}_{151}$ has enjoyed the attention of many scholars. It has always been considered as an example of early Arabic Bible translations, even when it was not the main focus of research. In the first volume of his monumental Geschichte der Christlichen Arabischen Literatur series, Georg Graf suggested that $\mathrm{S}_{15} 1$ was of unbestimmter Herkunft (indefinite origin) and therefore did not connect it with Ibn al-Sirrī (whom he mentions in another context), as he had no access to the Sinai collection. ${ }^{20}$

Harvey Staal offers us the broadest work on S151. It begins with his dissertation in 1969 that includes an edition and English translation of Romans, 1 and 2 Corinthians, and Philippians. ${ }^{21}$ In the introduction preceding this edition, Staal briefly surveys the history of the Monastery at Mount Sinai, its Arabic manuscripts, and the work of the American expedition that microfilmed many manuscripts in $195^{\circ} .{ }^{22}$ Additionally, he describes the manuscript on paleographical and codicological levels. He provides tables for the distribution of the books over the folios, and marks the different quires and scribal changes as well as a number of paratextual features. ${ }^{23}$ His work was expanded to include all the Pauline Epistles of S151, and it was published with an introduction and English translation in $1983 .{ }^{24} \mathrm{~A}$ year later, he edited and translated the Catholic Epistles and Acts of the Apostles of the same manuscript. ${ }^{25}$ With regard to the Pauline corpus, which is the main focus of this paper, Staal produced two introductions; the first one is an abridged form of his dissertation's introduction, in which he describes the manuscript's codicological, paleographical, and paratextual aspects. It also includes an explanation of Staal's strategy for editing

esians 5:1-12; 2 Thessalonians 2:1-12; Hebrews 3:1-11, in addition to some scattered verses from the substituted folios mentioned below.

20 Georg Graf, Geschichte der christlichen arabischen Literatur, vol. I, Studi e Testi 118 (Vatican: Biblioteca Apostolica Vaticana, 1944), 79, 153; Georg Graf, Geschichte der christlichen arabischen Literatur, vol. II, Studi e Testi 133 (Vatican: Biblioteca Apostolica Vaticana, 1947): 158-159.

21 Harvey Staal, "Codex Sinai Arabic ${ }_{151}$ Pauline Epistle (Part I)" (PhD diss., University of Utah, 1969); idem, "Codex Sinai Arabic ${ }_{151}$ Pauline Epistle (Part II)" (PhD diss., University of Utah, 1969).

22 Idem, "Codex Sinai Arabic ${ }_{151}$ Pauline Epistle (Part I)," 5-7.

23 Ibid., 14-15.

24 Harvey Staal, Mt. Sinai Arabic Codex 151, I. Pauline Epistles [Edition], Corpus Scriptorum Christianorum Orientalium $45^{2}$ (Leuven: Peeters, 1983); idem, Mt. Sinai Arabic Codex 151, I. Pauline Epistles [Translation], Corpus Scriptorum Christianorum Orientalium 453 (Leuven: Peeters, 1983).

25 Idem, Mt. Sinai Arabic Codex 151: Acts of the Apostles, Catholic Epistles [Edition], Corpus Scriptorum Christianorum Orientalium 462 (Leuven: Peeters, 1984); idem, Mt. Sinai Arabic Codex 151: Acts of the Apostles, Catholic Epistles [Translation], Corpus Scriptorum Christianorum Orientalium 463 (Leuven: Peeters, 1984). 
the text. The second introduction is quite short and precedes the English translation in a separate volume. As a result of working on a microfilm, he posits that two scribes transcribed the Pauline Epistles and the Acts of the Apostles and Catholic Epistles respectively. After his visit to the Monastery, where he examined the manuscript in person, he corrected himself in the edition's introduction. He also corrected mistakes such as suggesting that some of its folios are palimpsests. ${ }^{26}$ The parts he narrated in his introductions are integrated in this paper, corrected when necessary, and completed. It was Sebastian Brock who proposed a new perspective on $\mathrm{S}_{151}$. He connected the annotations of the manuscript to the East Syriac tradition, though not to a single commentator in this tradition. ${ }^{27}$

$\mathrm{S}_{15} 1$ is unique among other Arabic Bible manuscripts in several aspects. The text of the Arabic Bible is usually exhibited as a continuous text, specific passages devoid of their contexts for the liturgy, or passages followed by detailed commentary [Figure 7]. S151 combines some of the aforesaid characteristics by surrounding the continuous biblical text with glosses and short annotations. In its current state, $\mathrm{S}_{15} 1$ falls into 269 parchment folios. The number of lines per page varies, but the average is 18 to 23. Each epistle has a preface explaining the motivation for its writing. ${ }^{28}$ Hebrews, which is included as the last epistle in the Pauline Corpus, is preceded by a slightly longer introduction proving its Pauline authorship. ${ }^{29}$ Reflecting the Syriac tradition, the Pauline Epistles'

26 On his visit to the Monastery, see the preface in Staal, Mt. Sinai Arabic Codex 151, I. Pauline Epistles [Edition]; for the number of scribes compare, idem, "Codex Sinai Arabic 151 Pauline Epistle (Part II)," 22-23; and idem, Mt. Sinai Arabic Codex 151, I. Pauline Epistles [Edition], xi.

27 Sebastian P. Brock, "A Neglected Witness to the East Syriac New Testament Commentary Tradition: Sinai Arabic MS 151," in Studies on the Christian Arabic Heritage, ed. Rifaat Ebied and Herman Teule, Eastern Christian Studies 5 (Leuven: Peeters, 2004), 205-215; Féghali also examined the text of S151, using Staal's edition, and noted its Syriac Vorlage. See Paul Féghali, "Les épîtres de saint Paul dans une des premières traductions en arabe," Parole de l'Orient 30 (2005): 103-129; and also Samir Khalil Samir, "Michel évêque melkite de Damas au ge siècle. A propos de Bišr ibn al-Sirrī," Orientalia Christiana Periodica 53 (1987): 439441.

28 The Pauline Epistles are traditionally fourteen: Romans, 1 and 2 Corinthians, Galatians, Ephesians, Philippians, Colossians, 1 and 2 Thessalonians, 1 and 2 Timothy, Titus, Philemon, and Hebrews. In modern scholarship, only Romans, 1 and 2 Corinthians, Galatians, Philippians, 1 Thessalonians, and Philemon are undisputedly called Pauline Epistles. They are currently cited in the aforementioned order; however, they have previously had a variety of different orders. In particular, the Epistle to the Hebrews was sometimes located as the epistle number ten and in other times it was number fourteen.

29 This provides an evidence that the controversy over its authorship reached Arabic Christianity. See also Harvey Staal, "Pauline Authorship of the Epistle to the Hebrews According to Mt Sinai Arabic Manuscript 151," Reformed Review 21 (1967): 51-53. 
text is treated as a single corpus divided into 55 chapters. ${ }^{30}$ Similarly, Acts and the Catholic Epistles show the arrangement into one unit and are divided into $3^{2}$ chapters. ${ }^{31}$ There is a colophon at the end of the Pauline Epistles (ff. $186 \mathrm{v}-$ $187 \mathrm{r}$ ), which informs the reader that they were translated by Bišr ibn al-Sirrī in $253 \mathrm{AH} / 867 \mathrm{CE}$.

The manuscript has a complex syntax of primary and secondary layers; for example, some damaged folios were substituted, readers left notes and comments in the margins. There are also several colophons by the same hand in different places of the Pauline Epistles, three of which belong to Yūḥannā alYabrūdī. Information about the scribes who handled S151, together with its marginalia, will be unfolded and discussed in detail below. Table 2 exhibits the codicological division of the $\mathrm{S}_{151} 1$ in its current state and its contents.

TABLE 2 The quires and contents of $\mathrm{S}_{15}$

\begin{tabular}{lllll}
\hline Quires & Folios & Bifolia & Contents & Scribe \\
\hline No sign (1) & $1-3$ & 3 & Rom 1:1-2:6 & S$^{3}$ \\
\hline B $(2)$ & $4-11$ & 8 & $2: 7-5: 14$ & Ibn al-Sirrī \\
$\Gamma$ & $12-19$ & 8 & $5: 15-9: 13$ & \\
$\Delta$ & $20-27$ & 8 & $9: 14-11: 33$ & \\
E & $28-35$ & 8 & $11: 34-15: 31$ & \\
$\varsigma$ & $36-43$ & 8 & $15: 32-1$ Cor $3: 13 a$ & \\
\hline 7 & $44-47$ & 4 & 1 Cor $3: 13$ b-7:27 & S \\
\hline H & $48-55$ & 8 & $\begin{array}{l}7: 28-11: 15 \\
11: 16-14: 30 a\end{array}$ & Ibn al-Sirrī \\
$\Theta$ & $56-63$ & 8 & $14: 3$ ob-16:24 & \\
I & $64-71$ & 8 & 2 Cor $1: 1-4: 17$ & $S^{3}$ \\
\hline 11 & $72-75$ & 5 & &
\end{tabular}

30 Sebastian P. Brock, The Bible in the Syriac Tradition (Kottayam: St. Ephrem Ecumenical Research Institute, 1988).

31 The heading of chapter 32 is found in f. 261r (1John 3:21), and following it comes 2 Peter, 2 and 3 John, and Jude without new chapters. 
TABLE 2 The quires and contents of S151 (cont.)

\begin{tabular}{|c|c|c|c|c|}
\hline Quires & Folios & Bifolia & Contents & Scribe \\
\hline IB & $76-83$ & 8 & $4: 18-10: 9$ & Ibn al-Sirrī \\
\hline $\mathrm{I} \Gamma(13)$ & $84-91$ & 8 & 10:10-Gal 1:15 & \\
\hline $\mathrm{I} \Delta(14)$ & $92-99$ & 8 & $1: 16-4: 27$ & \\
\hline IE $(15)$ & $100-107$ & 8 & 4:28-Eph 3:1 оа & \\
\hline $\mathrm{I} \varsigma(16)$ & $108-115$ & 8 & 3:1 ob-Phil 1:9a & \\
\hline IZ (17) & $116-123$ & 8 & 1:9b-Col 1:19a & \\
\hline IH $(18)$ & $124-131$ & 8 & 1:19b-1 Thes $2: 20$ & \\
\hline $\mathrm{I} \Theta(19)$ & $132-139$ & 8 & 3:1-2 Thes 3:18 & \\
\hline K & $140-147$ & 8 & $1 \operatorname{Tm} 1: 1-6: 9$ & \\
\hline KA & $148-155$ & 8 & 6:10-Ti 1:4 & \\
\hline KB & $15^{6-163}$ & 8 & 1:5-Heb 1:5 & \\
\hline $\mathrm{K} \Gamma$ & $164-171$ & 8 & Heb 1:6-7:2 & \\
\hline $\mathrm{K} \Delta$ & $172-179$ & 8 & $7: 3-11: 6 a$ & \\
\hline $\mathrm{KE}$ & $180-187$ & 8 & 11:6b-colophon & \\
\hline 26 & $188-196$ & 9 & Acts $1: 1-5: 38 a$ & $\mathrm{~S}^{3}$ \\
\hline $\mathrm{KZ}$ & $197-204$ & 8 & $5: 38 b-9: 6$ & Ibn al-Sirrī \\
\hline 28 & $205^{-212}$ & 8 & $9: 7-12: 25$ & \\
\hline 29 & $213-220$ & 8 & $13: 1-16: 16 b$ & \\
\hline $3^{\circ}$ & $221-228$ & 8 & $16: 16 c-19: 35^{a}$ & \\
\hline 31 & $229-236$ & 8 & $19: 35^{b-23: 29}$ & \\
\hline 32 & $237-244$ & 8 & $23: 30-28: 11 \mathrm{a}$ & \\
\hline 33 & $245^{-25^{2}}$ & 8 & $28: 11 b-1$ Pet $1: 19 b$ & \\
\hline 34 & $253^{-26 o}$ & 8 & 1:19c-1Jn 3:17 & \\
\hline \multirow[t]{2}{*}{35} & $261-268$ & 8 & 3:18-Ju 12 & \\
\hline & 269 & Single folio & $12-25$ & $\mathrm{~S}^{3} ?$ \\
\hline
\end{tabular}

In this section, the history of this manuscript is reconstructed by narrating the three stages it went through, estimated from the manuscript itself and from other manuscripts that are witness to this same version. We begin with the 
longest stage, the newly made manuscript, which describes activities such as copying, corrections, and collation. The second stage is when S151 became a defective manuscript; details about this stage are lacking since they come to us via evidence from the third stage, that of the restored manuscript.

\subsection{The New S151a}

The text of the Pauline Epistles of S151 began its life in a separate production unit of 25 quaternion quires that occupy ff. 1-187; here, we will call this manuscript S151a. The beginning of each quire is marked in the upper-left corner with Greek letters and, sometimes, the upper-right corner features a cross framed by pyramid-shaped lines [Figure 1]. Starting from the end of quire nine, the scribe has also marked the ends of the quires-albeit inconsistentlyrepeating the Greek quire numbers and drawing simple crosses.

The text exhibited in S151a encompasses the biblical text of the 14 Pauline Epistles (Hebrews included) plus some annotations and glosses. These provide short explanations of select difficult or unusual words in the biblical text. The mise-en-page is arranged so that the biblical text usually occupies the upper part of the page in shorter lines and then the annotations appear in longer lines below. The biblical text occupies $7-14$ lines, and the annotations and the glosses $3^{-14}$ lines per page. The folio measurements are mostly the same $(25.4 \times 18 \mathrm{~cm})$, the ruled writing block is $19 \times 12 \mathrm{~cm}$ in f. $18 \mathrm{v}$, for example. ${ }^{32}$ Within the ruled writing blocks, the actual area occupied by writing varies due to the previously mentioned difference between the biblical and the annotations blocks. The biblical text is written in larger letters with more space between the lines. By contrast, the annotations are written in longer and denser lines and in somewhat smaller letters than the biblical text.

It appears that the scribe wrote the biblical passage at the beginning of the manuscript and then commented on it. Since he made several annotations on the same page, he had to use specific sigla to connect each annotation to its respective biblical word in the main text. These sigla are written in red and include many shapes, such as crosses, infinity, horizontal $(\mathrm{T})$ and $(\mathrm{Y})$ shapes, etc. [Figure 2]. The annotations are occasionally framed in red, probably to distinguish them from the biblical text and from each other. Sometimes, the comments are too long, requiring the scribe to move to the next page to

32 According to Atiya's catalogue, the page formats are $25.5 \times 17.5 \mathrm{~cm}$, the writing surface equals ca. $19 \times 12 \mathrm{~cm}$. See Atiya, Catalogue Raisonné of the Mount Sinai Arabic Manuscripts, 284 . 


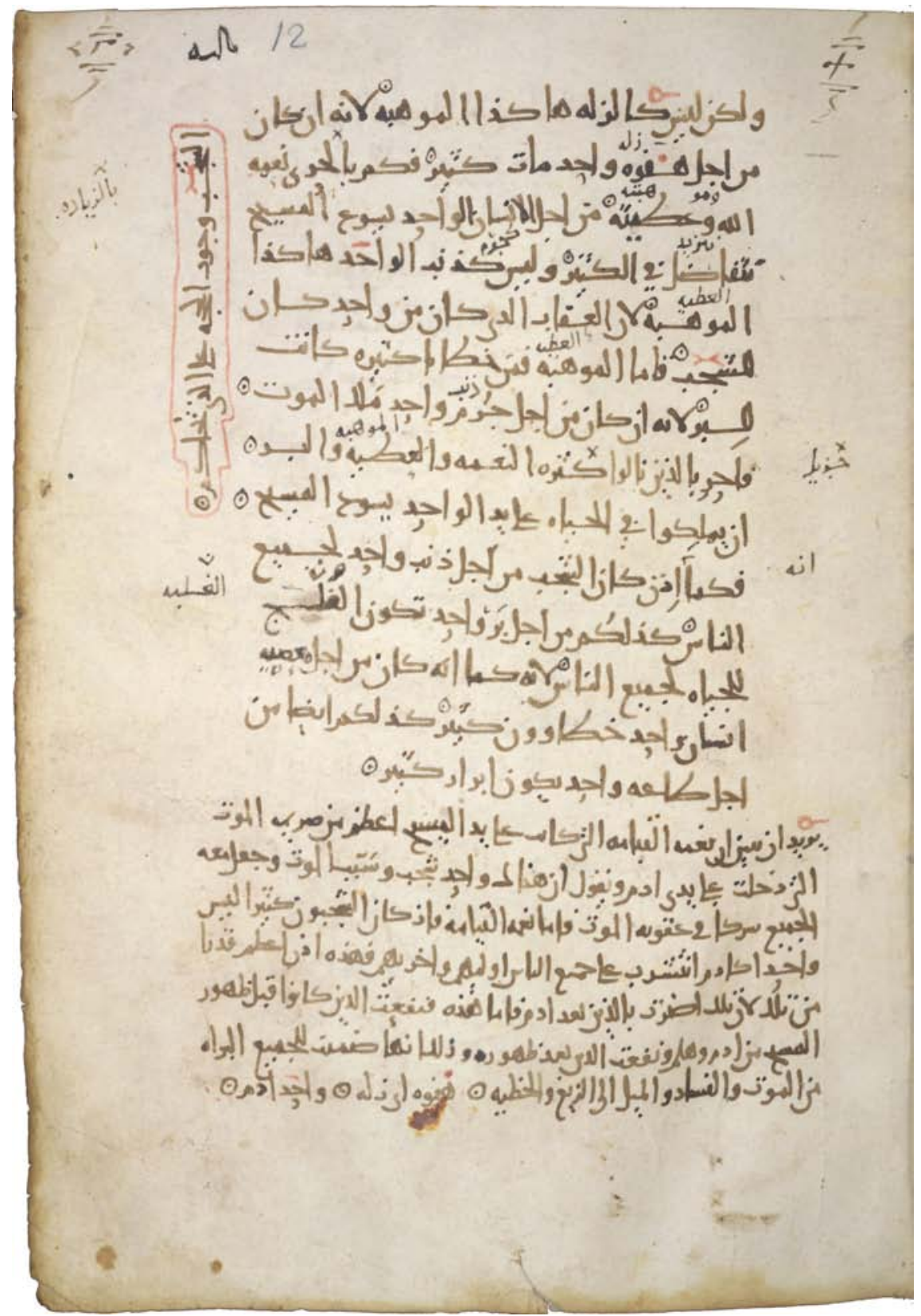

FIGURE 1 The Greek and Arabic quire marks, the decorated cross signs, and the sigla used in S151a (f. 12r)

PHOTOGRAPH COURTESY OF SAINT CATHERINE'S MONASTERY, SINAI, EGYPT. 
continue them. He then started a new biblical passage in the middle of the new page, again with shorter lines, and so on. In some cases, the scribe continued the annotations or wrote new ones vertically in the larger margins around the biblical text. This happened when he ran out of space, but wanted to insert these comments on the same page, or when he decided to add them later. This is perceived in Figure 2 where the last two sigla on the biblical text (red cross and thick dot) correspond to the two perpendicular annotations.

Furthermore, the prefaces that precede each epistle are written in smaller script and compact lines, just like the annotations. This layout means that S151a has a special place between biblical manuscripts that contain only the biblical text and those commentaries that contain short paragraphs of biblical text followed by long interpretations. As mentioned earlier, S151 stands here with its full biblical text along with short interpretations that do not conform to a fullyfledged commentary.

The script of S151a has some features of the New Abbasid Styles group of scripts, yet it forms a category by itself among the Christian Arabic scripts. ${ }^{33}$ The final alif has an extended stroke below the baseline (see Christian Arabic I in Hjälm's categories/late ninth century). The independent alif, however, shows two different shapes: frequently a straight terminated alif and sporadically the reversed 's' alif that characterizes the old Abbasid book hand (see Christian Arabic II in Hjälm's categories/ninth century). Whereas the vertical stroke of $t \bar{a} \mid z \bar{a}$ ' consistently slants to the right, the horizontal lines of these letters along with șād/dāa / middle kājf extend directly to the left dominating larger space (see Christian Arabic III in Hjälm's categories/tenth century); this is clearer in the case of the biblical text. Unlike the mentioned straight strokes, the final $l \bar{a} m, w \bar{a} w$, and $r \bar{a} / z \bar{a} y$ have cursive/semicircular endings. These characteristics, which combine features of more than one category, make the script of S151a a unique case. The ink is faint-brownish, yet the diacritical dots are rarely detected in the original ink. Short black slashes were apparently added later as diacritical marks, albeit inconsistently. There are a few vocalization marks by the original hand, and ihmāl signs below the $h \bar{a}$ ' and the 'ayn (see the word ma'anā in the eleventh line of Figure 2).

33 François Déroche, The Abbasid Tradition: Qur'ans of the 8th to the 1oth Centuries AD (London: Nour Foundation, 1992), 132-137; Hjälm has specified a category just for the paleography of this manuscript, see Hjälm, "Paleographical Typology of Early Christian Arabic Scripts (ca. 9th c.)." 


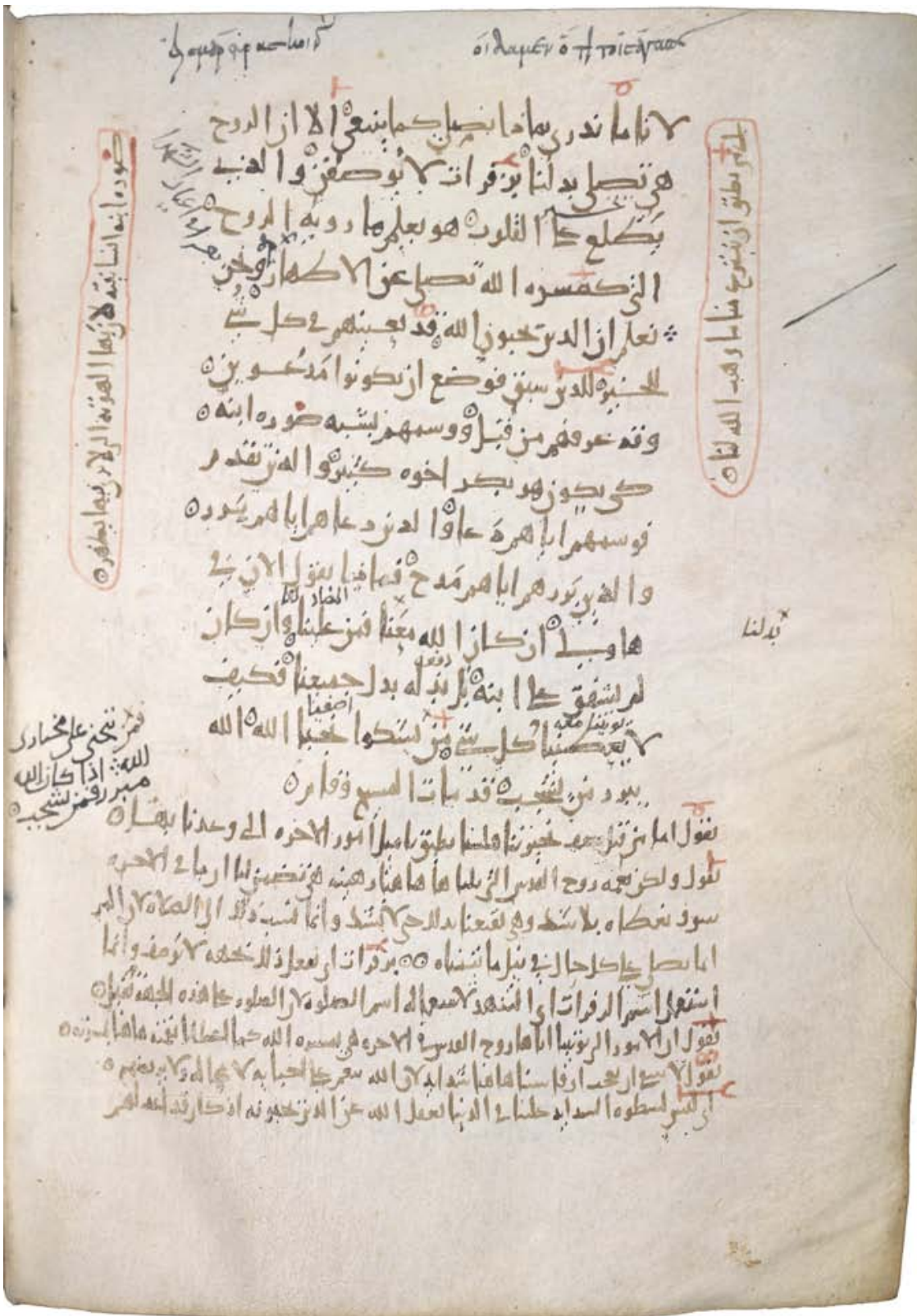

FIGURE 2 The original layout of S151a, and Arabic and Greek liturgical rubrics (f. 18v) PHOTOGRAPH COURTESY OF SAINT CATHERINE'S MONASTERY, SINAI, EGYPT. 
When it comes to the text, the Pauline Epistles of S151a represent one of the oldest translations of the Arabic Pauline Epistles, and a roughly faithful translation of the Peshitta Syriac Version. ${ }^{34}$ This can be seen from the following examples: ${ }^{35}$

\section{(1) 2 Corinthians 6:16}

S151a (fol. 78v): لانكم انتم هيكل الله الحي كما قيل اني اسكن فيهم واسير فيه

"because you are the temple of the living Göd; as it was said, I will dwell in them and walk in them."36

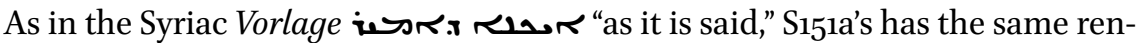

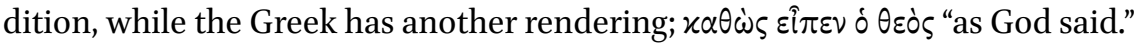

\section{(2) Hebrews 3:1}

$$
\begin{aligned}
& \text { S151a (fol. 166r): فالان يا اخوتي الاطهار الذين دعيتم بالدعوه التي من السما انظروا الى } \\
& \text { هذا الرسول }
\end{aligned}
$$

"Then now, my holy brothers, who have been called with the call, which is from heaven, look toward this apostle ..."

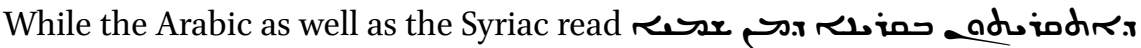
"who were called through the call from heaven," the Greek reads $x \lambda \eta \dot{\sigma} \sigma \omega \varsigma$ ह่ $\pi 0 \nu-$

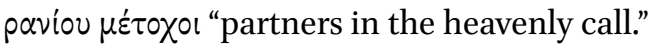

34 Staal thought that the Syriac exemplar from which the Pauline Epistles were translated originated from the so-called Alexandrian or Western text-type; see Staal, Mt. Sinai Arabic Codex 151, I. Pauline Epistles [Edition], 36-39.

35 The Greek and Syriac texts used for comparison in this paper are: Barbara Aland et al., eds, Novum Testamentum Graece: Nestle-Aland, 28th revised ed. (Stuttgart: Hendrickson, 2012); Barbara Aland and Andreas Juckel, eds, Das Neue Testament in syrischer Überlieferung, vol. II. Die Paulinischen Briefe/1 (Römer und 1. Korintherbrief), Arbeiten zur Neutestamentlichen Textforschung 14 (Berlin: De Gruyter, 1991); idem, eds, Das Neue Testament in syrischer Überlieferung, vol. II. Die Paulinischen Briefe/2 (2. Korintherbrief, Galaterbrief, Epheserbrief, Philipperbrief und Kolosserbrief), Arbeiten zur Neutestamentlichen Textforschung 23 (Berlin: De Gruyter, 1995); idem, eds, Das Neue Testament in syrischer Überlieferung, vol. II. Die Paulinischen Briefe/3 (1./2. Thessalonicherbrief, 1./2. Timotheusbrief, Titusbrief, Philemonbrief und Hebräerbrief), Arbeiten zur Neutestamentlichen Textforschung 32 (Berlin: De Gruyter, 2002).

36 Unless otherwise mentioned, I use the literal translation in Staal, Mt. Sinai Arabic Codex 151, I. Pauline Epistles [Translation]. 
The colophon at the end of S151a (ff. 186v-187r) reads [Figure 3]: ${ }^{37}$

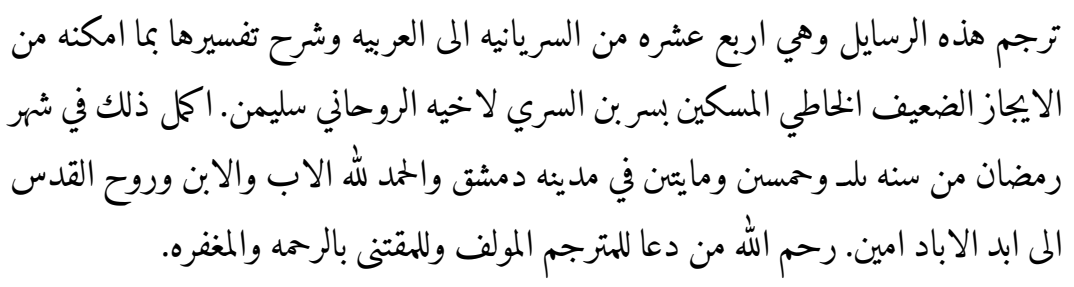

The one who translated these epistles, which are fourteen, from Syriac to Arabic and explained their interpretation as briefly as he could is the weak sinner, poor Bišr ibn al-Sirrī to his spiritual brother Sulaymān. And, he completed this in the month of Ramaḍann of the year $253[\mathrm{AH}]$ in the city of Damascus. Praise be to God the Father, and the Son, and the Holy Spirit for ever and ever. Amen. May God have mercy upon the one who prays for the translator, and the author and the owner, with mercy and forgiveness. ${ }^{38}$

The translator, Bišr ibn al-Sirrī, worked in Damascus and wrote two homilies that are extant in Mss Sinai, Ar. 400 and Sinai, Ar. $401 .^{39}$ S151a reveals nothing about his denominational affiliation. On the contrary, it suggests two different affiliations. ${ }^{40}$ As mentioned above, Brock points out that the annotations Bišr

37 The second earliest colophon in the Arabic Bible manuscripts is extant in Ms. Sinai Ar. NF, Parch. 14 (859 CE), but it was re-dated to $873 \mathrm{CE}$ according to Swanson. See Kashouh, The Arabic Versions of the Gospels, 86-89; and Swanson, "Some Considerations for the Dating of Fī Tațlìt Allāh al-Wāhịid (Sin. Ar. 154) and al-Ǧāmic Wuğūh al-Īmān (London, British Library Or. 4950)."

38 The translation in Staal reads: "These letters which are fourteen, have been translated from Syriac into Arabic, and the weak, poor, sinner Bishr ibn al-Sirrī, has explained their comments as was possible for him, briefly, for his spiritual brother Solomon. And he completed that in the month of Ramadhan, of the year two hundred and fifty-three, in the city of Damascus. And praise to God the Father, and the Son, and the Holy Spirit, forever and ever. Amen. May God have mercy upon the one who prays for the translator, and the author and the owner, with mercy and forgiveness." See Staal, Mt. Sinai Arabic Codex 151, I. Pauline Epistles [Translation], 26o (fn. 23).

39 Alexander Treiger, "From Theodore Abū Qurra to Abed Azrié: The Arabic Bible in Context," in Senses of Scripture, Treasures of Tradition: The Bible in Arabic among Jews, Christians and Muslims, ed. Miriam L. Hjälm, Biblia Arabica 5 (Leiden: Brill, 2017), 23 (n. 122); Both manuscripts are dated to the thirteenth century; see Kenneth W. Clarke, Checklist of Manuscripts in St. Catherine's Monastery, Mount Sinai: Microfilmed for the Library of Congress, $195^{\circ}$ (Washington, DC: Library of Congress, 1952), 35 .

40 After the council of Ephesus and the condemnation of Nestorius (431 CE), the Eastern Churches gradually embarked on different paths due to complicated Christological 
added below the text reveal an East Syriac tendency. ${ }^{41}$ In contrast, the readings in the biblical text itself reveal a more non-East Syriac 'Orthodox' inclination. A famous example is Hebrews 2:9 (fol. 165r) that reads in S151a, هو بنعمة الله or, "he, by the grace of God" in accordance with most Syriac manuscripts and the oldest Greek manuscripts as a translation of the Greek $\chi \dot{\alpha} p \iota \tau \iota \theta \varepsilon \circ \hat{v}$. Another famous reading that became known from its connection to the East Syriac tradition is "without God," as a rendition of the Greek $\chi \omega$ pı $\theta \varepsilon \circ 0.42$ The latter reading is what Bišr inserted in the annotations along with an interesting comment that reads:

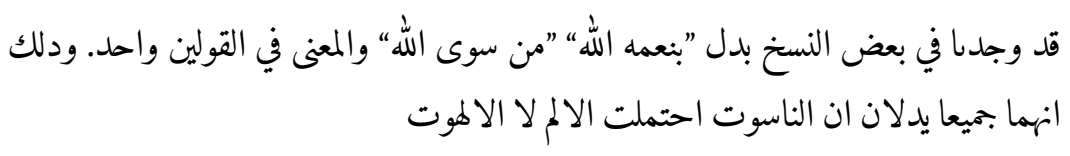

We have found in some copies, instead of 'by the grace of God,' 'without God,' and the meaning of the two phrases is one that is indicative that humanity bore the pain, not divinity. ${ }^{43}$

Bišr, then, uses the non-East reading in the main text, and the East reading in the annotations, which might indicate that he is not an East Syriac. However, his diplomatic comment harmonizes the meaning of both variants, which leads to puzzlement regarding his denominational affiliation. The ambiguity escalates as the name of Bišr ibn al-Sirrī is confused with other authors and translators. ${ }^{44}$ The debate over Ibn al-Sirri's affiliation remains unsettled; some scholars, such as Samir Khalil, Nasrallah and, most recently, Griffith, are inclined to put Bišr in the Melkite (Chalcedonian) realm. ${ }^{45}$ Meanwhile, Brock anticipates

conflicts. It is not expected therefore that the variant readings that became connected to the East Syriac Church "Nestorian" found their way into and can be reconciled with the orthodox readings. For the history of the East Syriac Church, see Wilhelm Baum and Dietmar W. Winkler, The Church of the East: A Concise History (London: Routledge, 2010).

41 Brock, "A Neglected Witness to the East Syriac New Testament Commentary Tradition," 208.

42 This reading reached a number of Syriac manuscripts from a few Greek manuscripts, such as those that bear the numbers $0243,1739^{*}$, $\mathrm{vg}^{\mathrm{ms}}$.

43 Staal, followed by Brock, translates it as "on behalf of God"; see Staal, Mt. Sinai Arabic Codex 151, I. Pauline Epistles [Translation], 228; Brock, "A Neglected Witness to the East Syriac New Testament Commentary Tradition," 208.

44 See the list in Brock, "A Neglected Witness to the East Syriac New Testament Commentary Tradition," 214.

45 Griffith, The Bible in Arabic, 134; Joseph Nasrallah, "Deux versions melchites partielles de la Bible du Ixe et du xe siècles," Oriens Christianus 64 (1980): 134; Samir, "Michel évêque melkite de Damas au ge siècle. A propos de Bišr ibn al-Sirrī." 


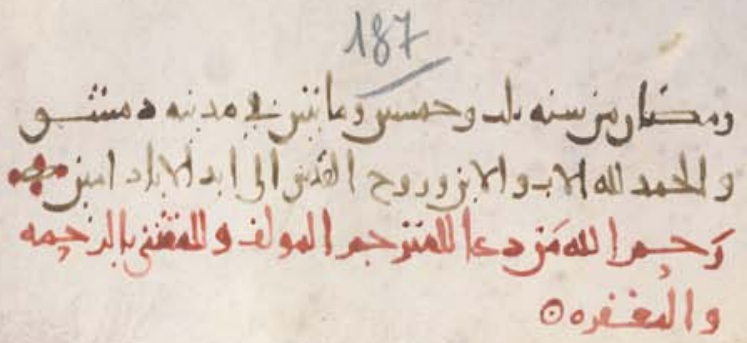

FIGURE 3 Part of the colophon in S151 (f. 187r)

PHOTOGRAPH COURTESY OF SAINT CATHERINE'S MONASTERY, SINAI, EGYPT. 
that his annotations insinuate that he belongs to the East Syriac tradition, but suggests that the issue requires more investigation. ${ }^{46}$

S151a's first owner is anonymous; the only thing we know about him is his name 'Sulaymān'. Bišr describes him in the colophon as ahīhi al-rūhānī, "his spiritual brother," which seems a personal dedication rather than referring to the patron or the commissioner of the manuscript. To the best of my knowledge, colophons in Arabic Bible manuscripts from the same period generally do not have patrons. Examples from the Arabic Pauline Epistles' manuscripts are: the colophon of MS St Petersburg, NLR, A.N.S. 327 (892 CE), which bears only the date and does not even name the scribe. Also, the colophon of MS Vatican, Ar. 13, which is dated to the tenth century, and which has the name of the scribe and the books he transcribed, although without dates. Moreover, while late colophons providing information about manuscript patrons utilized roughly the same verbs as those used in Islamic manuscripts such as istaktaba, ihtamma, bi-rasm, S151a does not mention any commission. ${ }^{47}$ Scribes usually also described the patrons with qualities related to their high status or piety, yet S151a describes the relationship between the scribe and the target person.

It is intriguing that Ibn al-Sirrī used the hiğrī date in his colophon. Regarding this date, Griffith comments:

It is notable that a Christian copyist working in Damascus in the middle of the ninth Christian century is already dating his text, intended for Christian readers, according to the Islamic calendar, with no corresponding Christian dating. This usage bespeaks an already high degree of acculturation on the part of Arabic-speaking Christians in this milieu to the prevailing public conventions of the world of Islam. ${ }^{48}$

Nevertheless, this habit was not uncommon in Arabic Bible manuscripts. For instance, MS St Petersburg, NLR, A.N.S. 327, which is also translated from Syriac

46 Graf also puts him in the East Syriac tradition, see Graf, Geschichte der christlichen arabischen Literatur, 1944, I:16o; Brock, "A Neglected Witness to the East Syriac New Testament Commentary Tradition," 228-229.

47 For example, the colophons in other manuscripts that contain the Pauline Epistles in Arabic such as Mss Cairo, CM, Bible 94; Sinai, Ar. 168; Oxford, Bodl. Arab. d. 19 employ the terms al-sayyid "the master", al-ra'šs "the head or the chief", and rajul Allāh "the man of God" as qualities attributed to the patrons. For other terms that are used to introduce patronage in Islamic manuscripts, see Gacek, The Arabic Manuscript Tradition, 197. 

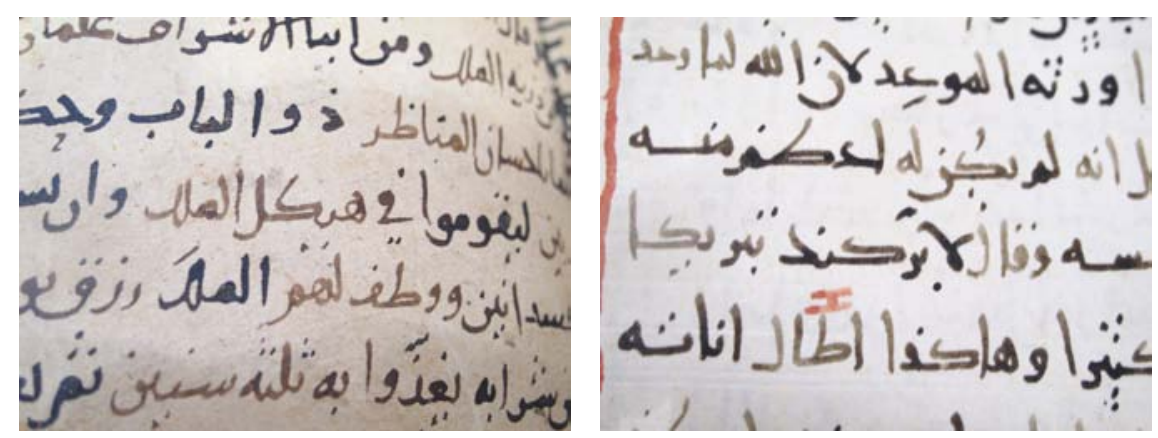

FIGURE 4 At the left the letter kā $f$ in Sinai, Ar. 2 (f. 247r) and at the right the letter kāf "final and middle" in Si51a (f. 171r)

PHOTOGRAPHS COURTESY OF SAINT CATHERINE'S MONASTERY, SINAI, EGYPT.

source texts is also dated using the hiğri date $273 \mathrm{AH} / 892 \mathrm{CE} .{ }^{49}$ In other cases, the higrri date was combined with other calendars, such as in the Ms Sinai, Ar. 159 , whose colophon is dated $6707 \mathrm{am} / 596 \mathrm{AH} / 1199 \mathrm{CE}$.

Joshua Blau prompted a debate about the correct interpretation of the date in the manuscript: since the colophon was written in the middle of the whole manuscript ( $\left.\mathrm{S}_{151}\right)$, i.e. after the Pauline Epistles and before the book of Acts and the Catholic Epistles, he thought that it must have been copied with the manuscript and this therefore dates only the text of the Pauline Epistles and not the manuscript itself. In other words, Ibn al-Sirrì did indeed translate the Pauline Epistles in $867 \mathrm{CE}$ and then another scribe later copied his translation including Ibn al-Sirri's colophon. It seems that the absence of another colophon at the end of the whole manuscript convinced Blau that the colophon must have been copied with the manuscript. ${ }^{50} \mathrm{He}$ thus estimated a post- $867 \mathrm{CE}$ date for the manuscript. ${ }^{51}$ Others consented to Blau's argument based on paleographical reasons. The handwriting of the scribe of $\mathrm{S}_{15}{ }^{1}$ is similar to that of MS Sinai, Ar. 2, which is dated to $939 / 940$ CE. ${ }^{52}$ Figure 4 shows that although the overall impression of the two manuscripts looks similar, there are significant variations in their writing styles. For instance, the final $k a \bar{f} f$ in S151a has an acute angle, while the same letter has a distinct right angle in Sinai, Ar. 2.

49 See the edition of part of this manuscript and its colophon in Edvard Stenij, Die altarabische Übersetzung der Briefe an die Hebräer, an die Römer und an die Corinther. Aus einem in St. Petersburg befindlichen Codex Tischendorfs vom Jahre $892 \mathrm{n}$. Chr (Helsinki: Frenckellska Tryckeri, 1901).

$50 \quad$ See Joshua Blau, "Über einige Christlich-Arabische Manuskripte aus dem 9. und. 10. Jahrhundert," Le Muséon: Revue d'Études Orientales 75 (1962): 107.

51 See also Griffith, "The Monks of Palestine," 17.

$5^{2}$ Treiger, "From Theodore Abū Qurra to Abed Azrié," 23, 25. 
In her ongoing study on the paleography of the Arabic Christian manuscripts, Miriam Hjälm points out that the observed similarity might indicate the common origin of the two manuscripts in Damascus. ${ }^{53}$

Moreover, the text of S151a shows no signs of being copied in the case of the sample passages I worked on. Issues that mark a copied text, like homoeoteleuton, haplography, or dittography, do not appear in S151a. ${ }^{54}$ Additionally, on select pages, a few of the annotations and comments on the text were written vertically, because there was no space to write them on the horizontal lines of the same page. The misjudging of the required space is more likely to happen when a scribe is translating. During copying, he will have an approximation of the space needed for writing, but in translation, estimating the necessary space is harder.

The original layout of S151a influenced its circulation. The mise-en-page established by the initial scribe allowed for-and possibly also invited-considerable free space that was later filled by several scribes or readers. They added variant readings, comments, rubrics of lections, or marks for the Old Testament quotations. ${ }^{55}$ These layers of marginalia indicate, using Griffith's statement, that "the manuscript had an active life in the church; it was intended to serve both homiletic, even catechetical, as well as liturgical purposes. ${ }^{56}$ There are, nevertheless, more indications of the active life of S151a that are not commonly known. I focus here on two of them: copying and collations/corrections.

\subsubsection{Copying Si51a}

The text of S151a is extant in three later manuscripts that vary in many ways. They do not share the same epistles' order and chapter division of S151a, nor do they copy all of its paratextual features. The process of copying Si51a started early, as attested by the first manuscript witness to its text, which is dated to the tenth century. The three manuscript-witnesses will be introduced chronologically in order to establish a clearer relationship with their archetype ( $\left.\mathrm{S}_{1512}\right)$ : Sinai Greek NF MG2 is S151a's earliest witness, and it is among the new findings

53 I appreciate the help of Miriam Hjälm, who also pointed out to me other dissimilarities in other letters, such as the middle round 'ayn in Sinai, Ar. 2 versus the heart shape 'ayn in S151a.

54 Homoeoteleuton is a frequent cause of omission in copied manuscripts due to joining similar ends in near lines together; haplography is omission of similar letters, syllables, words, or lines during copying; and dittography is repeating some letters or words unintentionally while copying. For more details on other scribal errors, see Gacek, The Arabic Manuscript Tradition, 234-235.

55 Staal, Mt. Sinai Arabic Codex 151, I. Pauline Epistles [Edition], x.

56 Griffith, The Bible in Arabic, 135. 
from St Catherine's Monastery in Egypt (1975).${ }^{57}$ Its importance lies in the fact that it is a palimpsest parchment in 115 folios. The ancient underlying text contains parts of the Greek Old Testament books, such as Ezekiel and Jeremiah, in addition to many other fragmented works. The upper text comprises bilingual Greek-Arabic Pauline Epistles in two columns. ${ }^{58}$ The text contains: Romans 1:1-10, 24b-30; 1 Corinthians 7:37-8:6a; some minor fragments in between; and Galatians $1: 2$ to the end of the Pauline Epistles. 1 and 2 Timothy are completely missing, and the current binding puts Titus and Philemon after Hebrews. This manuscript's binding is notably loose. It is formed using a number of barely connected quires, then, starting from folio 109, there is an individual folio that has part of the Epistle to the Hebrews and then another loosely connected four folios whose text is part of the Epistles to Titus (one folio) and Philemon. This last quire is in poor shape with many mostly deteriorated folios, and other folios are missing. The only pagination is modern, probably made by the cataloguer; any older numbering relates only to the quires. Table 3 exhibits the remaining quires along with their contents.

The manuscript encompasses one codicological unit; that said, the formation of the original quires was inconsistent from the beginning, as shown in Table 3. Most of the surviving quires have eight bifolia, yet two quires include six bifolia. It is likely that 1 and 2 Timothy preceded Titus and Philemon and followed Hebrews. The number of the quires between Galatians and Hebrews makes it difficult to fit all the epistles from Ephesians to 2 Timothy before Hebrews. Since the order of the epistles sometimes reveals the tradition in which the manuscript was copied, I will explain the order of this manuscript in detail: 2 Thessalonians ends on the first folio of quire $x \theta(29)$ and is followed by Hebrews. Quire $\Lambda$ (30) follows directly and ends with Hebrews 6:7, then Quire $\lambda \alpha$ (31) comes next and starts with Hebrews 6:8. It stands to reason that Hebrews followed 2 Thessalonians directly, for it is impossible to fit 1 and 2 Timothy before Hebrews. This implies that Hebrews was number ten, as occasionally happens in the Melkite or Greek-Orthodox order of Pauline Epistles. It is likely that 1 and 2 Timothy were removed when the manuscript was torn, and

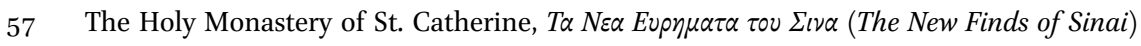
(Athens: Ministry of Culture-Mount Sinai Foundation, 1999), 141. However, its contents are recorded in this catalogue as the Epistle to the Hebrews only. Moreover, it is dated to the ninth century, but the paleographical features of the Arabic text refer to the tenth century.

$5^{8}$ It retains the number 0278 in Aland-Gregory Uncial's list of New Testament manuscripts. The details of the Greek text and the lower script are in Hieromonk Justin of Sinai and Jack Tanus, "Exploring a Ninth Century Sinai Palimpsest" (2010). 
TABLE 3 The quires and the contents of MG2

Quires Extant folios Bifolia Contents ${ }^{\mathrm{a}}$

\begin{tabular}{|c|c|c|c|}
\hline A-IH $(1-18)$ & $1 \mathrm{r}-12 \mathrm{~V}$ & - & $\begin{array}{l}\text { Rom } 1: 1-9 ; 24-30,1 \text { Cor } 7: 37-40 \text {; } \\
8: 1-6 \text {; fragments with Greek or } \\
\text { Arabic letters only } 2 \text { Cor } 13: 3-4 \text {; } \\
7-12 ; \text { Gal } 1: 1-3: 1\end{array}$ \\
\hline $\mathrm{I} \Theta(19)$ & $13 \mathrm{r}-2 \mathrm{OV}$ & Eight & Gal 3:2-5:10 \\
\hline $\mathrm{K}(20)$ & $21 \mathrm{r}-26 \mathrm{v}$ & Six & Gal 5:11- \\
\hline $\mathrm{KA}(21)$ & $27 \mathrm{r}-3 \mathrm{OV}$ & Four & $\begin{array}{l}\text { Gal 5:12-end; Eph } 1: 4-8 ; 1: 16- \\
2: 14 ; 3: 9-4: 8 \text {; fragments with few } \\
\text { Greek and Arabic words }\end{array}$ \\
\hline $\mathrm{KB}(22)$ & $31 \mathrm{r}-38 \mathrm{v}$ & Eight & Eph 4:30-end \\
\hline $\mathrm{K} \Gamma(23)$ & $39 \mathrm{r}-47 \mathrm{v}$ & - & Phil 1:1-3:4; 4:12-13; 4:17-21 \\
\hline $\mathrm{K} \Delta-\mathrm{KE}(24-25)$ & $48 \mathrm{r}-54 \mathrm{~V}$ & - & Col 1:17-3:13 \\
\hline $\mathrm{K}_{\varsigma}(26)$ & $55^{\mathrm{r}-6 \mathrm{ov}}$ & Six & Col 3:21-end; 1 Thess 1:1-2:5 \\
\hline $\mathrm{KZ}(27)$ & $61 \mathrm{r}-68 \mathrm{v}$ & Eight & 1 Thess $2: 5^{-5} 5: 3$ \\
\hline $\mathrm{KH}(28)$ & $69 r-76 v$ & Eight & 1 Thess $5: 3$-end; 2 Thess $1: 1-3: 4$ \\
\hline $\mathrm{K} \Theta(29)$ & $77 \mathrm{r}-84 \mathrm{v}$ & Eight & 2 Thess 3:4-end; Heb 1:1-3:6 \\
\hline$\Lambda(30)$ & $85^{r-92 v}$ & Eight & Heb $3: 6-6: 8$ \\
\hline$\Lambda \mathrm{A}(31)$ & $93 \mathrm{r}-100 \mathrm{v}$ & Eight & Heb 6:8-8:6 \\
\hline$\Lambda \mathrm{B}(32)$ & $101 \mathrm{r}-109 \mathrm{v}$ & - & Heb 8:6-10:12 \\
\hline & 11 or $-115 \mathrm{~V}$ & - & Tit 2:1 1-3:2; 3:8-end; Phlem 1-end \\
\hline
\end{tabular}

a I appreciate the help of Fr. Justin of St Catherine's, who shared with me the division of the text per folio that he had prepared earlier.

then the folios that contain the epistles up to and including Titus and Philemon were placed after Hebrews.

The Arabic handwriting of MG2 is inconsistent, curvy, mostly dotted New Abbasid style, and is not neatly written [Figure 6]. The manuscript also contains Greek rubrics of lections according to the Jerusalemite system and, with a later hand, according to the Constantinopolitan system in Hebrews. ${ }^{59} \mathrm{MG} 2$ has a note of waqf in f. $115 \mathrm{v}$ to the Monastery of Sinai without a specific date [Figure 5]:

59 Justin of Sinai and Tanus, "Exploring a Ninth Century Sinai Palimpsest," 8-9. 


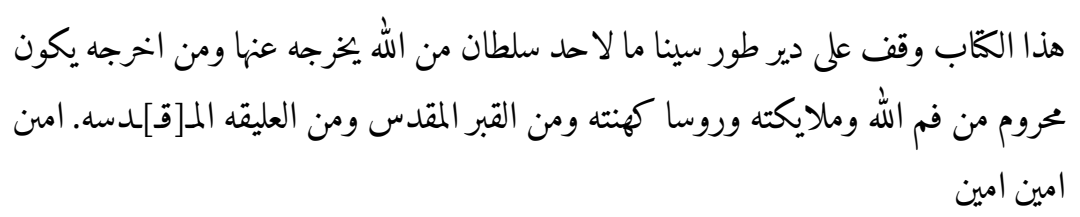

This book is endowed to the Monastery of Tūur Sīnā', none has authority from God to bring it out of it, and whoever brought it out is excommunicated [by a word] from the mouth of God, and his angels, and chief priests, and the holy grave, and the holy bush. Amen amen amen!

The Greek text is classified among a specific category of the majuscules with a certain angle of inclination to the right. Geographically, they belong mostly to the Orient (Sinai-Palestine-Damascus). A number of them, such as Mss Sinai, Ar. 34-36, are Greek-Arabic psalters and, unlike the Byzantine custom, they usually begin with the hair-side of the parchment, in accordance with the Arabic custom. ${ }^{60}$ These 'sloping pointed Majuscule' manuscripts began to appear in the second half of the ninth century and continue to exist until the late tenth century. ${ }^{61}$ This is a period of a century and a half, and all we can say about the date of $\mathrm{MG} 2$ is that it is post $867 \mathrm{CE}$, the date of its archetype, probably in the tenth century. The same scribe of the Greek text also transcribed MS Vatican Gr. 2282, a scroll containing the Liturgy of St. Mark in Greek with Arabic captions. ${ }^{62}$ This manuscript was transcribed in Damascus since its scribe wrote prayers to the archbishop of the city. This makes one wonder whether MG2 was directly copied from S151.

6o Dieter Harlfinger, "Beispiele der Maiuscula Ogivalis Inclinata vom Sinai und aus Damaskus," in Alethes philia. Studi in onore di Giancarlo Prato, ed. M. D'Agostino, Collectanea 23 (Spoleto: Centro italiano di studi sull' alto medioevo, 2010), 461-464.

61 Examples of these kinds of manuscripts are mentioned by Orsini and include: 1. Sin. gr. 210 + Sin. NE MГ 12 + Petropol. BAN RAIK 194 + Sin. Harris App. 16, 22 (861/862 CE) 2. Petropol. RnB Gr. $216+$ Sin. NE MГ 33 (862/863 CE) 3. Vat. gr. 354 (949 CE) 4. Sin. gr. 213 + Petropol. RNB gr. 283: 967AD 5. Sin. ar. 116: 995/996AD. See Pasquale Orsini, "La maiuscola ogivale inclinata. Contributo preliminare," Scripta 9 (2016): 89-116. See also another list in Lidia Perria, "Scriture e codici di origine orientale (Palestina, Sinai) dal IX al XIII secolo. Rapporto preliminare," Rivista di Studi Bizantini e Neoellenici 36 (2000): 2425 .

62 Francesco D'Aiuto, "La "scrittura mista" maiuscolo-minuscola d' area mediorientale," in Griechisch-byzantinische Handschriftenforschung: Traditionen, Entwicklungen, neue Wege, ed. Christian Brockmann et al. (Berlin: De Gruyter, 2018), 162, 164-165 (fn 4), 168 (fn 24). 


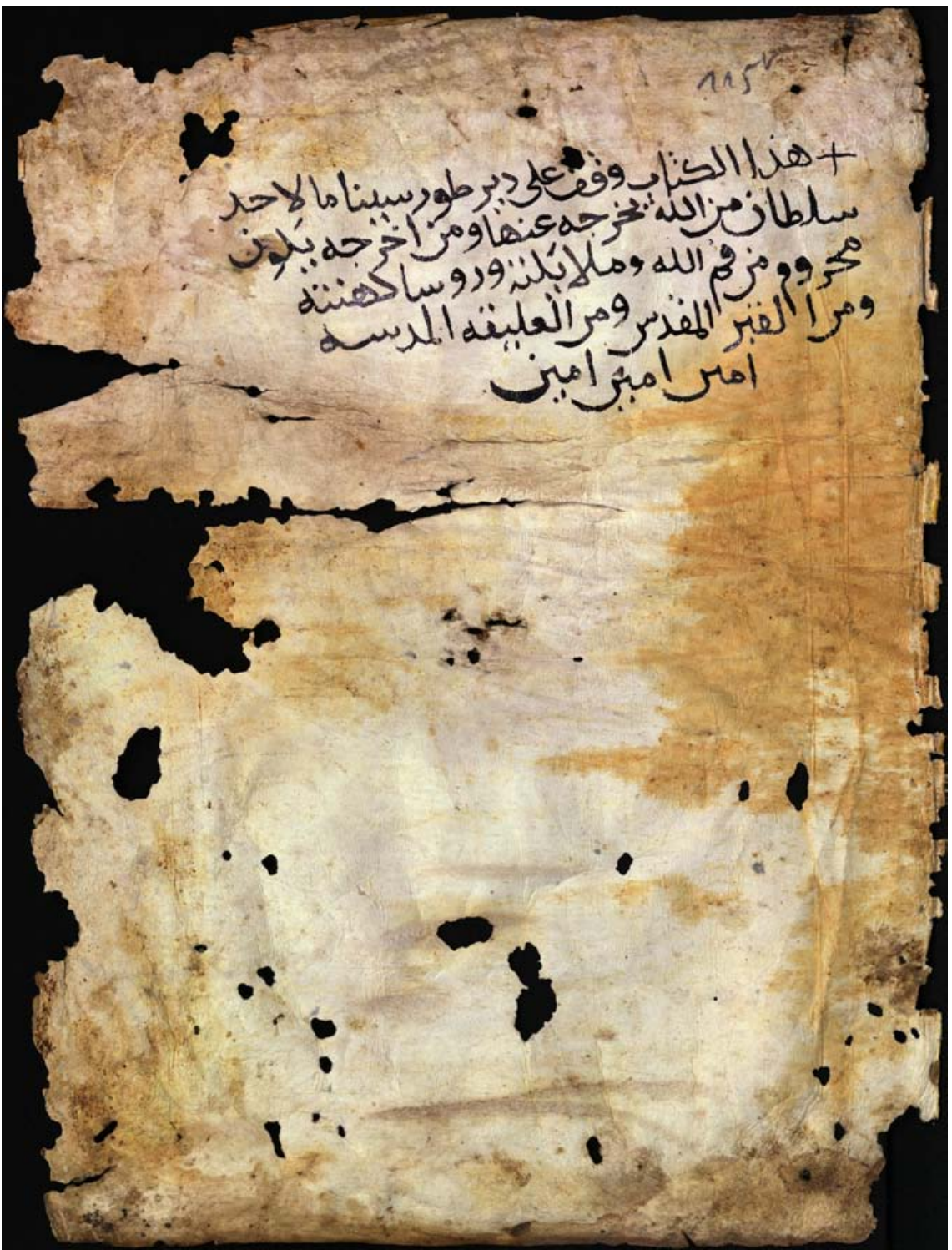

FIGURE 5 Waqf note in $\mathrm{MG}_{2}$ (f. 115v)

PHOTOGRAPH COURTESY OF SAINT CATHERINE'S MONASTERY, SINAI, EGYPT. 


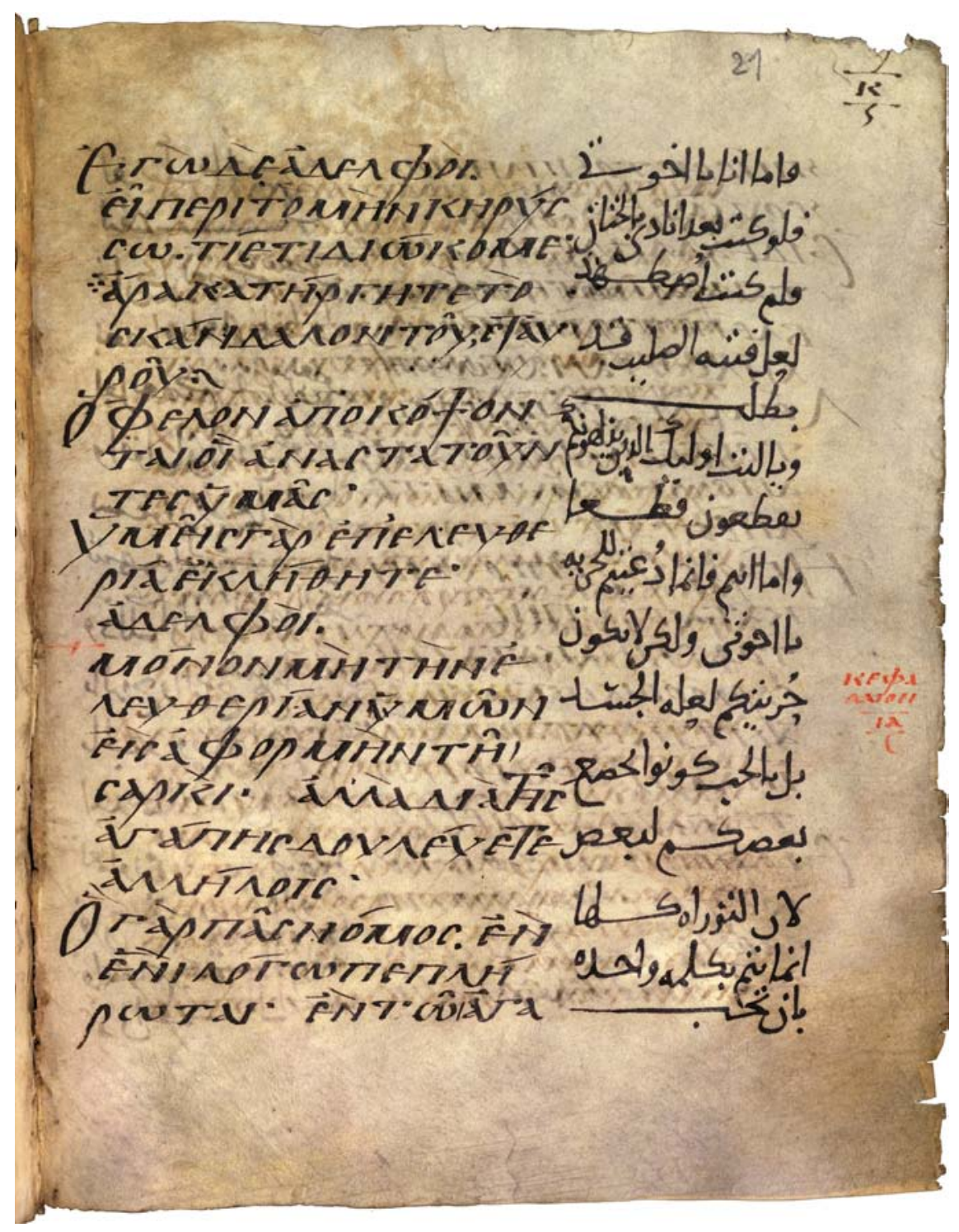

FIGURE 6 The layout of MG2 (f. 21r)

PHOTOGRAPH COURTESY OF SAINT CATHERINE'S MONASTERY, SINAI, EGYPT. 
The second manuscript-witness is Berlin, Staatsbibliothek zu Berlin, Diez A Oct. 162 (6773 creation/1264CE). ${ }^{63}$ The manuscript (hereafter B162) is composed of 348 folios of yellowish paper with small, neat, fully-vocalized nash handwriting. ${ }^{64}$ Its contents include the books of the NT; indeed, it is the earliest volume to collate all of them. Their order is: the Gospels; Pauline Epistles; Acts of the Apostles; Catholic Epistles; and Revelation. The Pauline Epistles occupy ff. $163 \mathrm{a}-263 \mathrm{~b}$ and, as in S151a, they end with Hebrews. Moreover, in this version, for the first time each epistle is divided individually into chapters. The epistles' titles are written as in deluxe manuscripts in golden ink outlined with black ink, and several colours, such as blue and red, are used either in titles or to shape circles to separate verses. There are also a few Latin notations in the margins of several folios (ff. 175B, 176a, 192b, 193a, 225a). ${ }^{65}$

The whole manuscript is comprised of 31 quires and, with the exception of a few, most of them are six bifolia. For instance, the last quire of the Pauline Epistles is eleven folios (five bifolia in addition to a single folio). The first quire and part of the second quire are missing (the text begins at Matthew 10:29). The scribe left two folios empty at the end of the Gospels (quire 15) and started the Pauline Epistles in a new quire. There is also a separate quire count in Arabic letters for the Gospels alone and for the book of Acts and the epistles together; the Gospels begin with quire 2 and extend to quire 15 and the Pauline Epistles are written in 9 quires (quires $16-24$ of the total number of the quires in the manuscript). However, the book of Acts begins in the middle of the last quire of the Pauline Epistles (quire 9 of the unit of the epistles and Acts, and 24 of the whole number of the manuscript's quires) and extends to the middle of quire 13/28. The Catholic Epistles begin directly in the same quire and extend only until the end of quire 14/29. The Book of Revelation begins at the top of quire 30 and ends on the next quire (31). The manuscript has clearly been through some conservation process, as evidenced by the many adhesive tapes used to attach parts of the same folios to each other. Guards and stubs are also used for some folios, but it is not possible to say when exactly they were put in place.

Despite the fact that the whole manuscript is one production unit, clearly produced by the same scribe, he wrote only one colophon. Moreover, the

63 W. Ahlwardt, Die Handschriften-Verzeichnisse der Königlichen Bibliothek zu Berlin, vol. 9, Verzeichniss der Arabischen Handschriften 21 (Berlin: A. Asher \& C., 1897), 527-529 (10175); Graf, Geschichte der christlichen arabischen Literatur, 1944, I:177; Caspar René Gregory, Textkritik des Neuen Testamentes: Die Übersetzung-die Schriftsteller-Geschichte der Kritik., vol. II (Leipzig: J.C. Hinrichs, 1902), 587 (69).

64 A digitized copy of the whole manuscript is available on the Staatsbibliothek zu Berlin website: http://bit.ly/2U6rmbM

65 Gacek, The Arabic Manuscript Tradition, 61, 122. 
colophon is located at the end of the Gospels (f. 16or), without the scribe's name; it reads:

$$
\text { وذلك في العشر الأوّل من شهر أيار لسنة ست ألاف وسبع مائه لله وسبعين للعالم }
$$

And this [was accomplished] in the first ten days of May of the year 6773 of creation.

According to a waqf note on f. $263 \mathrm{v}$, at a certain point in its history, this manuscript was related to the Balamand Monastery and the church of Mar. Girgis:

$$
\begin{aligned}
& \text { هدا الكّاب المبارك المسما انجيل(التترا؟) ورسايل (الترا؟) وقفاً موبداً وحبساً مخلداً على دير }
\end{aligned}
$$

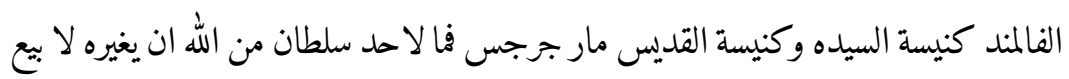

$$
\begin{aligned}
& \text { ولا رهن ولا بوجه من وجوه الانتقاليه وكلمن تجاسر واخده يكون تحت الحرومات واللعنات } \\
& \text { القاطعه سرمداً }
\end{aligned}
$$

This blessed book, which is called the [tetra] Gospel and the [tetra] Epistles is an eternal endowment to the Balamand Monastery, the Church of the Lady, and the Church of St George. Thus, none has authority from God to change this, through selling or loan nor through any means of transmission. Whoever dares to take it, may [he] be under excommunication and firm curses forever.

A sentence that reads waqf dayr al-Balamand is repeatedly written on the upper margins of several folios, for example, ff. $4 \mathrm{~V}-6 \mathrm{r}$. Until 7175/ $1666 \mathrm{CE}, \mathrm{B} 162$ was probably in the Near East; a reading note on the last folio (f. $349 v)$ refers to this:

$$
\text { نضر في هذا الانجيل المقدس ابراهيم ابن المرحوم سليمان سنة }
$$

Ibrāhīm the Son of the late Sulaymān has [looked] into this Holy Bible in the year $7175 / 1666 \mathrm{CE}$.

Its transfer to the Benzlius collection in Uppsala is vague; ${ }^{66}$ there, it held the shelf mark Benzel 5. In 1804, it was sold, along with the whole collection, to

66 The catalogue does not mention anything about its history of acquisition, see Caroli 
Heinrich Friedrich von Diez, whose collection entered the Königliche Bibliothek, now the Staatsbibliothek zu Berlin ( (ввв), in $1817 .{ }^{67}$ Graf referred to the Syriac origin of the Pauline Epistles of this manuscript. ${ }^{68}$ To the best of my knowledge, only two works have studied this manuscript in detail. The first was by Julius Heinrich Petermann, a German orientalist from the nineteenth century, who gathered all the versions of Philemon in the Oriental languages that he could access and edited them in parallel lines. ${ }^{69}$ Among them, were five Arabic versions and one of them was the text of B162. The second work on B162 was done by Hikmat Kashouh in his study of the Arabic Gospels manuscripts that involved almost 210 manuscripts. He classified B162's text as the only representative of what he called 'Family $(\mathrm{N}) \cdot{ }^{\prime}{ }^{70}$ The text of the Gospels in this manuscript exhibit a markedly free translation:

Synonymous expressions and explanatory phrases are added continuously throughout the text of this manuscript. Consequently, it becomes difficult to ascertain the text type of the Vorlage of this version. ${ }^{11}$

The third manuscript-witness to S151a is Florence, BM L, Conv. Soppr. 532 (F532): a late-thirteenth-century manuscript written in fully dotted and considerably vocalized nash..$^{72}$ It is arranged in 127 folios that exclusively include the Pauline Epistles. This is the only witness to S151a that copied the introductions preceding each epistle, and the only one that retained the old Syriac division of the epistles as one corpus, as used in the archetype. ${ }^{73}$ After Tit 2:1, there is a lacuna

Auriuillii, Recensio Codicum Manuscriptorum ab Henrico Benzelio (Uppsala: Litteris Edmannianis, 1802), $5^{-8}$. Its existence in two different catalogues confused Gregory, who registered it twice, one as Benzel 5 , and the other under its current shelf mark in Berlin (p. 587). See Gregory, Textkritik des Neuen Testamentes.

67 Christoph Rauch, "The Oriental Manuscripts and Albums of Heinrich Friedrich von Diez and the Perception of Persian Painting in His Time," in The Diez Albums, 2016, 74-75.

68 Graf, Geschichte der christlichen arabischen Literatur, 1944, I:177.

69 His edition includes versions in Arabic, Armenian, Ethiopian, and Syriac. See Julius H. Petermann, ed., Pauli epistola ad Philemonem speciminis loco ad fidem versionum orientalium veterum una cum earum textu originaligraece (Berlin: Sumptibus C.G. Lůderitz, 1844).

70 Kashouh, The Arabic Versions of the Gospels, 276-280.

71 Ibid., 278.

72 It retains number 807 in Italo Pizzi, Index Codicum Manuscriptorum Orientalium qui in Bibliotheca Medicea-Laurentiana Florentiae adservantur (Florence: Bibliotheca MediceaLaurentiana Flor. adservantur, 1881); see also Bernadette Martel-Thoumian, Les manuscrits arabes déposés à la Bibliothèque Medicea Laurenziana de Florence: Nouvelles acquisitions (Florence: Department of Languages, University of Florence, 1997), 17-18.

$\mathrm{F}_{532}$ is thus the only witness to the introductions that were part of the lost folios of S151a, 
in the manuscript until $3: 8$, and then a new scribe continues writing until the end of the manuscript (Philemon). The order of the epistles in this manuscript is unusual, with Hebrews as number twelve (after 2 Timothy and before Titus). This cannot be explained as an erroneous order of the quires because its position is clearly stated in the subscription of 2 Timothy (f. $106 \mathrm{v}$ ), which reads:

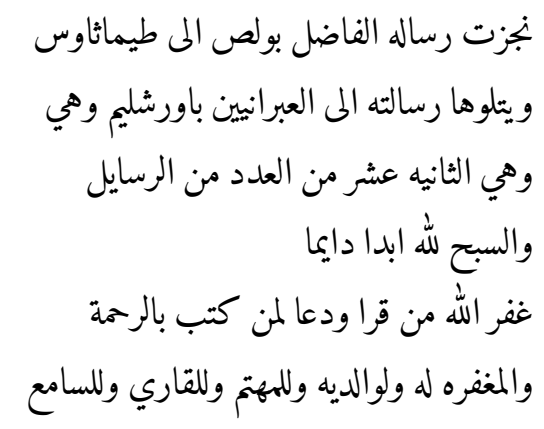

The epistle of the reverend Paul to Timothy is accomplished And following it his epistle to the Hebrews in Jerusalem, which is the twelfth in number of the epistles the praise to God for ever and ever.

May God forgive those who read and prayed for mercy upon the one who wrote

And for forgiveness to him and to his parents, and to the one who cares, and the one who reads, and the one who listens.

It was probably in Europe that the titles of the epistles, such as ad Timotheum, were written in the upper margin in thin, Latin handwriting (see f. 10or). In addition, the bifolia containing the text of some epistles are numerated in Latin numerals; for instance, Romans' bifolia are numbered I-XVIII $(6 \mathrm{v}-7 \mathrm{r}$ to $26 \mathrm{v}-$ $27 \mathrm{r}$ ). There is apparently no original pagination; modern folio numbering is detected on the lower left margin.

This manuscript was used in liturgy, as can be seen from the sentence ismac min huna "listen from here [this verse]", that is frequently written in a small, neat hand in the margins alongside the beginning of a new reading. The end of a reading is sporadically marked by a $h \bar{a}^{\prime}$ letter, referring to the verb intah $\bar{a}$

namely, the introduction to Romans, which is slightly long because it contains a summary about Paul and his life. The second introduction missing from $\mathrm{S}_{15} 1$ is that of 2 Corinthians, which, surprisingly, has two short introductions in F532. Each offers different reasons as to why Paul wrote this epistle (see below, the defective $\mathrm{S}_{151 \mathrm{a}}$ ). 
"is finished", which was commonly used at the end of a passage. ${ }^{74}$ It seems that these rubrics were part of the original design of the manuscript.

Some variant readings and corrections are written in the margins (ff. 6v-7r).

Some Arabic liturgical rubrics are occasionally added in the margin in a different hand. For example, the rubric alongside Philippians 3:1 rubric reads: الحد "Sunday after Nativity", and the rubric of Philippians 3:13 reads: "Sunday after Epiphany”.

The total number of quires is fifteen, the first two quires of which, in addition to quires 12-13, are not numbered. The numbering of quires starts on $\mathrm{f}$. $22 \mathrm{r}$ (quire 3) and, subsequently, it is succeeded by the quaternion quires. This, together with a stub between $\mathrm{ff}$. 21-22, implies that the first two quires both had eleven bifolia. The last quire, also a quaternion, is followed by two free folios that were attached by a stub. The script is different in these two folios, suggesting that they were part of the restoration of the manuscript. That said, the text in them is still the same text of the archetype.

The bifolia are numbered using Syriac numbers and sometimes, for unknown reasons, the numeration turns to pagination and then returns to bifolia numbering. For instance, f. $29 \mathrm{v}$ is numbered using Syriac numeration (31), f. 3 or is numbered (32), f. 3 ov has no number, but the numeration continues from the next folio 31r, which is numbered (33). The following pages are successively numbered f. $31 \mathrm{v}$ (34), f. $3^{2 \mathrm{r}}(35)$, f. $3^{2 \mathrm{v}}$ (36), yet the numbers become confused again with f. $33 \mathrm{r}$ numbered (38), f. $33 \mathrm{v}$ having no Syriac numeration, and f. $34 \mathrm{r}$ is (39). It seems that this numeration was inconsistently used as pagination and bifoliation.

Examining different verses from the four manuscripts, it becomes evident that they are indeed the same version. Table 4 gives examples from various Pauline Epistles. It clarifies the accuracy of the text and the extent of variations among the four witnesses.

The table confirms that all the manuscripts are witnesses to the same version. Galatians 3:15-17, for example, is roughly the same in all the manuscripts. There is a noticeable variation in styles, though, among the different manuscripts, for example the use of اربع مأيه/ اربع مايه /اربعمايه. We also see some distinct recensions in, for example, Galatians 3:15 of Sinai MG2, which reads as al-imān versus al-insān in the other recensions. This is probably a scribal error as it reads $\dot{\alpha} \nu \theta \rho \omega \dot{ } \omega_{0} \cup$ "man" in the Vorlage. The same recension employs al-itm in 2 Thessalonians 2:3 versus the synonym al-hațiyya in the other recensions.

74 See several forms of this siglum in Gacek, The Arabic Manuscript Tradition, 76, 117. 
S151
MG2

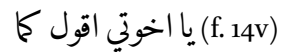

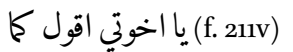

يا ياختي اقول كا (f. 65v)

$3: 15^{-17}$

$$
\text { ليقال بين الناس ان وصيه }
$$

يقال بين الناس ان وصيه الأسان ... ان الوثيقه التي اللة اللي الايمان ... ان الوثيقه التي

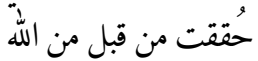
في المسيح التوراه التي كانت من بعد اربع مايه

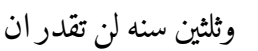
ترذله وتبطل الموعد في المسيح التوراه التي من من كانت من بعد اربعمايه سنه وثلثون سنه لن نقدر ان نرذلها ونبطل الموعد

يقال بين الناس ان وصيه الانسان ... ان الوثيقه

التي حققت من قبل من التئه اللهّ في المسيح النامس تئس الذي جا من بعد اربع مأيه وثلثين سنه لن يقد ارع انيرذلهاو يبطل الموعد

$\mathrm{F}_{532}$ يقال بين الناس ان وصيه الانسان ... ان الوصيه

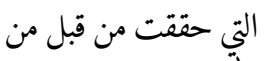

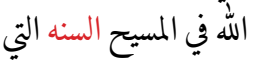
كانت من بعد اربع مايه

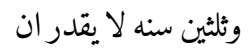

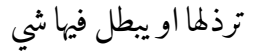

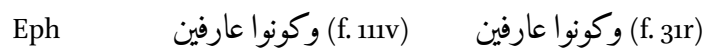
وكونوا عارفين (f. 219r)

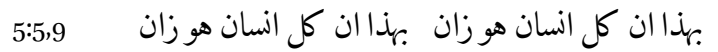

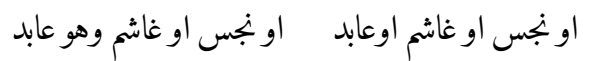

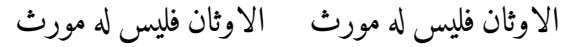

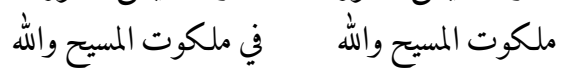
وكونوا تميزون ما الاحسن وكونوا تميزون ما الاحسن

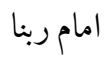

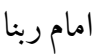

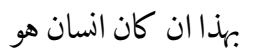

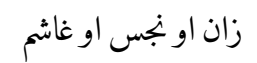
وكونوا عارفين (f. 74r) بهذا ان كل انسان هو

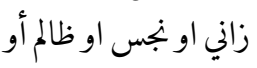
عابد وثن فليس لهولا اوعابد الاوثان فليس له اونه مورث ملكوت المسيح

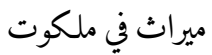
وكونوا ميزوا ما الاحسن مات المستح المسيح وكونوا ميزوا ما مات ميروات

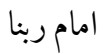

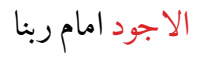

2Thess $2: 3$

$$
\begin{aligned}
& \text { لعل انسانا (f. 136v) لعل انسانا يضلكم (f. 74r) }
\end{aligned}
$$

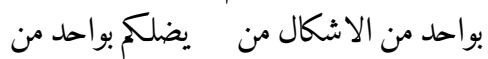

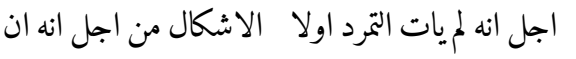

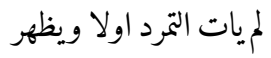
انسان الخطيه ابن الهلاك أمرد ولظك
ويظهر السان الاثم ابن أنم الهاكك
لعل انسانا (f. 235v)

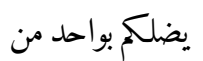
الاشكال من اجل انه ان من

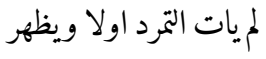
انسان الخطيه ابن الهلاك وكرد ولغك
لعل السانا يضلكم (f. 93v)

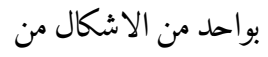

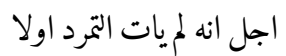

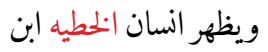
الهلاك و

Heb

$$
\text { (f. 166v) وكيوم التجربه في (f. 85r) }
$$

(ff. 251v-252r) (f. 111r)

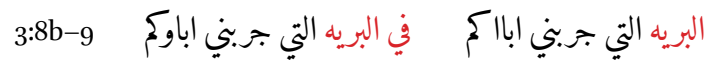

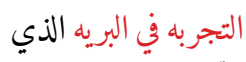
جريوه في التيه الذي

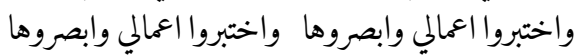
اربعين سنه. اربعين سنه 
Closer examination also reveals that the text of $\mathrm{F}_{532}$ is the most distinct from S151a and the other manuscripts in terms of changes of vocabulary and grammatical constructions. Thus, it is deemed an individual recension of this version, while the other three manuscripts represent another recension. An example of the vocabulary change is found in Ephesians 5:9, which, in the former manuscript, reads al-ajwad, while in S151a and all the other recensions it reads as the synonym al-ahsan. In terms of changing the construction of the sentence, Hebrews 3:8 in F532 has a verbal sentence with a unique construction:ومثل اليوم الذي جريوه, "and as the day that they have tested", as opposed to the nominal sentence in the other three manuscripts as well as the Syriac version, which reads: وكيوم التجربه في البريه and as the test day in the wilderness." This can possibly be explained by a collation or a series of collations against other ver$\operatorname{sion}(\mathrm{s}) / \operatorname{Vorlage}(n)$, or perhaps it is simply a scribal error. In some verses, there are more variations than others among the four manuscripts, such as in Galatians 3:17. In this verse, the oldest two manuscripts employ the term tawrāh, while B162 employs the term nämūs, and finally $\mathrm{F}_{53} 2$ uses sunna. The opposite happens in Romans 3:9, while the two oldest manuscripts read sunna and the two more recent manuscripts read tawrāh. This indicates a preference for the term sunna, sometimes even in later manuscripts. ${ }^{75}$

There is no evidence or sign in the three copies connecting their texts to the original translator, Bišr ibn al-Sirrī. The copies of S151a had different characters and served different functions: The bilingual manuscript (MG2) was probably used in liturgy since the Greek text has lections rubrics. The Berlin manuscript was part of one of the earliest complete New Testament in Arabic. Finally, F532's function appears to have been liturgical and as a study Bible; the introductions of the epistles were copied and the margins also include signs of the beginning and end of liturgical readings. No surviving manuscript-witnesses of S151a copied the annotations, which might be due to their East Syriac affiliation.

\subsubsection{Collation and Corrections}

Another sign of Si51a's active life is the collation and correction processes it served and that were applied to it. The different handwritings and inks in the marginalia of S151a imply more than one scribe; nevertheless, only one of them signed his name and appears to have produced most of them. The person responsible for this collation process was the West Syriac "Jacobite" physician Yūḥannā ibn Sahl al-Yabrūdī (eleventh century). He is also known for commis-

$75 \quad \mathrm{~B} 162$ and $\mathrm{F}_{532}$ share an interesting reading in agreement with the Philoxenian Syriac in Ephesians 5:5. Other Greek and Syriac Vorlagen read "in the kingdom of Christ and God," but the text in these two manuscripts reads "in the kingdom of Christ" only. 
sioning the translations of Dionysius the Areopagite's works from Greek in MS Sinai, Ar. $268 .{ }^{76}$ His affiliation to the Jacobite Syriac Orthodox Church is identified through Ibn Abī Ușaybīa's's book, 'Uyūn al-Anbā’ fi Țabaqāt al-Ațibbā̄o or The Best Accounts of the Classes of Physicians. ${ }^{77}$ Although al-Yabrūdī was a Jacobite, he was connected to the East Syriac circles as a student of the East Syriac scholar 'Abd Allāh ibn al-Tayyib. He possessed S151a from at least 1021 to 1025 , according to his three dated collation notes, which function as reports of which parts of the manuscript he used and how. ${ }^{78}$ Since he was mostly a resident of Damascus, it might be that $S_{15} 1$ was still in the city until this time. The first note on (f. 159v) is the longest of the three and reads:

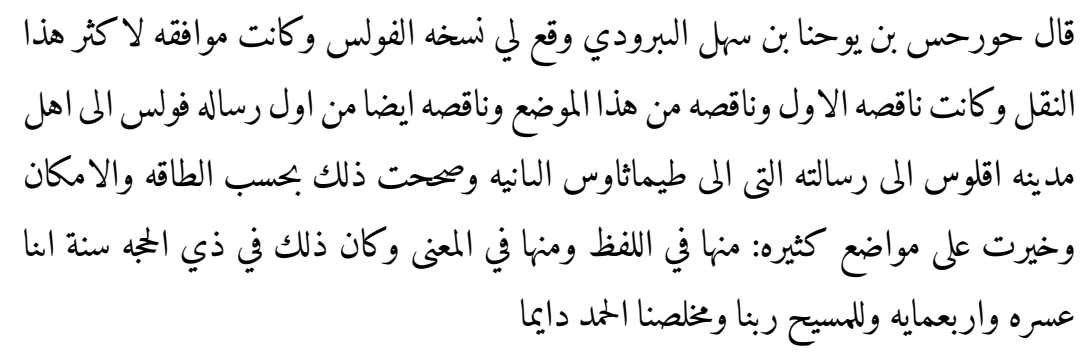

Jūrjis bin Yūḥannā bin Sahl from Yabrūd came upon a copy of Paul, and it was in agreement with most of this copy [151a], and it was lacking at the beginning, and lacking at this place, and lacking also from the beginning of the letter of Paul to the people of Colossae to his second letter which was to Timothy; and I corrected that according to ability and possibility, and I improved upon it in many places, sometimes in composition and sometimes in meaning. And that was in [the month of] Dhū al-Hijjah in the year four hundred and twelve $[\mathrm{AH}]$, and to Christ our Lord and our savior be the praise always. ${ }^{79}$

$7^{6}$ Alexander Treiger, "New Evidence on the Arabic Versions of the Corpus Dionysiacum," Le Muséon 118, no. 3-4 (2005): 219-240; idem, "The Arabic Version of Pseudo-Dionysius the Areopagite's," Le Muséon 120, no. 3-4 (2007): 240; He is also connected to other medical manuscripts in private collections that Sbath previously had access to, but their fate is currently unknown. See Juan Pedro Monferrer-Sala, "Al-Yabrūdī," in Christian-Muslim Relations: A Bibliographical History, ed. David Thomas and Alexander Mallett, vol. III, 1050-1200 (Leiden: Brill, 2011), 127-129.

77 See section 15.3 in the new Brill Database of Ibn Abī Ușaybía, 'Uyūn al-Anbā' fı Țabaqāt al-Ațibbä' (The Best Accounts in the classes of Physicians) at http://bit.ly/2OPuPI8.

78 Staal, followed by Brock, has calculated the hijrī years to correspond to 1030 and $1034 \mathrm{CE}$ respectively. See Staal, Mt. Sinai Arabic Codex 151, I. Pauline Epistles [Edition], xi.

79 Ibid., 219-220. 
What we grasp from this report is that, in 1021, al-Yabrūdī possessed another copy of the Pauline Epistles that concurs with most of S151a's naql, "copy," but it was wanting in some places that he counts as hād $\underline{a}$ al-mawdic, "this place." He refers to the beginning of Philemon, where he inserted his colophon in the margin, and a big lacuna, or lost folios, from Colossians to 2 Timothy. Thus, alYabrūdī used it to correct another manuscript that we are currently unaware of. Four years later, he wrote two more dated collation notes in (f. $38 \mathrm{v}$ ) at the end of Romans, and in (f. gov) at the end of 2 Corinthians. The two notes read respectively:

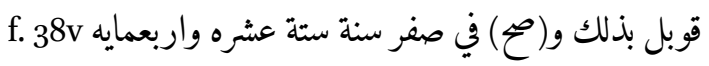

It was collated and (corrected/was found correct) in Șafar in the year $416 . .^{80}$

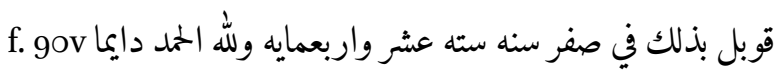

It was collated in Șafar in the year 416 and to God be the praise always. ${ }^{81}$

Around these two collation notes, mainly in Romans and 1 and 2 Corinthians, one finds many variant readings in al-Yabrūdì's hand..$^{82}$ This marks that, in this case, he used another manuscript to add variant readings, a few missing words or phrases, and a few comments or interpretations to S151a. Staal correctly records that al-Yabrūdī added several glosses and remarks to S151a, but nothing from the text. ${ }^{83} \mathrm{Al}-$ Yabrūdī utilized a number of sigla to denote his variant readings and comments in the text as well as in the margins. He used a thin reed pen when writing, and he had a unique way of writing some letters, such as the triangular beginning to $q \bar{a} f$ and $f \vec{a}$. Other than the three epistles that he collated extensively, we occasionally find variant readings by him.

80 Staal translates it as: "this was reviewed and corrected in [the month of] Safar of the year four hundred and sixteen [AH]"; see Staal, Mt. Sinai Arabic Codex 151, I. Pauline Epistles [Translation], 49 .

81 Staal translates it as: "This was reviewed in the month of Șafar in the year four hundred and sixteen, $[\mathrm{AH}]$ and to God be the praise always"; see Ibid., 119 .

82 There is another short, undated collation note by al-Yabrūdī at the end of Ephesians (f. 114v) that reads: "it was collated with this, and the praise is for our savior forever" قوبل بذلك والحمد لمخلصنا دائماً.

83 Staal, Mt. Sinai Arabic Codex 151, I. Pauline Epistles [Edition], xi. 
The question, then, is: which version(s) did he use to add these variant readings? One of the employed versions is probably translated from a Syriac Vorlage. Most of the variant readings added are synonyms for words in the original text of S151a. We find many of them in Romans 3, for instance: șidq for haqq "truth" in verse 5; hamdihi "praising him" for mağdihi "glorifying him" in verse 7; and sabaqnā for taqaddamna "precede" in verse 9. However, we also find a number of unusual readings, such as the variant reading of verse 4. S151a committed to the Syriac Vorlage, which reads is a liar," and rendered it وكل انسان كاذب, "and every man is a liar." The variant reading added by al-Yabrūdī over the original text is "even though every man lied." 84 Among the different versions of the Pauline Epistles in Arabic, this reading is notably close to the reading in MS St. Petersburg, NLR, A.N.S. 327. This manuscript is the earliest witness to another version of the Pauline Epistles in Arabic of the Syriac Vorlage. It is dated $892 \mathrm{CE}$ and known for its East Syriac readings and Qur'anic extensions. In the St Petersburg manuscript, this part reads as: وان كذب الناس, "even though all the people lie." ${ }^{85}$ Interestingly, the variant reading in S151a uses the singular insān, not the plural that is employed in the St Petersburg manuscript. Yet, the latter is the only early manuscript I know of that employs a conditional sentence in this verse.

Another remarkable variant reading exists in 2 Corinthians 6:12. S151a renders it mahabbatakum "your love," closer to the Greek $\sigma \pi \lambda \dot{\alpha} \gamma \chi$ vors i $\mu \omega \hat{\omega}$, which offers more possibilities to translate it as compassion or tender mercies ver-

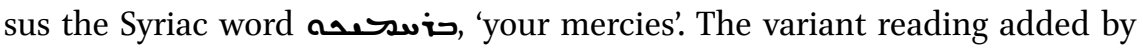
al-Yabrūdī reads rahmatakum "your mercy." This reading is also different from that in the St Petersburg manuscript, which reads akšăhakum "your bowels." ${ }^{86}$ The net result is that al-Yabrūdī was probably refining the readings of S151a to make it closer to the Syriac Vorlage. He did so either by adding synonym variant readings or other readings that he thought more accurate. He might have used a Syriac manuscript directly for his collation or an Arabic version from Syriac that we do not have access to today.

Moreover, there is evidence that al-Yabrūdī had access to a Greek text, or an Arabic translation from Greek. In two cases, he mentions in his marginalia that a certain reading in the text is different in Greek, and he records it. For

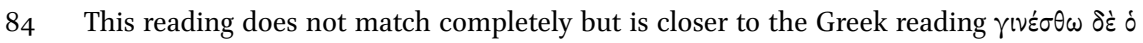
$\theta \varepsilon \dot{\varsigma} \varsigma \dot{\alpha} \lambda \eta \theta \dot{\eta} \varsigma, \pi \hat{\alpha} \varsigma \delta \dot{\varepsilon} \alpha \dot{\alpha} \theta \rho \omega \pi \circ \varsigma \psi \psi \varepsilon \dot{\sigma} \sigma \tau \eta \varsigma$, "let God be true, even though every man is a liar." The English Standard Version reads, "though everyone were a liar."

85 Stenij, Die altarabische Übersetzung der Briefe an die Hebräer, 29.

86 Ibid., 57 . 
instance, 1 Corinthians 7:34 in S151a reads: وبين المراه وبين العذرا فرق "and there is a difference between a wife and a virgin." He added a signal above the word al-mar[']a, and in the margin he clarifies that "this chapter does not exist in the Greek [text]." Turning to the Greek manuscripts, we notice that this verse has many transpositions and omissions of words and phrases. Nonetheless, the words he mentioned are not omitted in the manuscripts that are available now. He therefore either misplaced the siglum over this word, or had another manuscript where this word is also omitted. ${ }^{87}$ Another variant reading exists in 1 Corinthians 10:8; the number mentioned is twenty-three thousand. Yet, alYabrūdī adds a marginal note stating: في اليوناني اربعة, "in the Greek: four", to the effect that the number in Greek is twenty-four thousand. In fact, some Greek manuscript witnesses do give the number as twenty-four thousand, i.e. Minuscules 81 and 1175. It seems, then, that even though al-Yabrūdī had access to Greek readings and recorded them in the margins, he was generally faithful to the Syriac Vorlage and corrected the text, between the lines, where it did not concur with it).

\section{$2.2 \quad$ The Defective Si51a}

At some point in its circulation, probably as a consequence of the "active life" described above, S151a lost several folios. Whether this happened over a short or long period is not clear. The lost folios are $2 \mathrm{r}-3 \mathrm{r}, 44 \mathrm{r}-47 \mathrm{~V}$, and $72 \mathrm{r}-75 \mathrm{v}$. These constitute ten folios representing the following sections of the Pauline text: Romans 1:1-2:6; 1 Corinthians 3:13-7:27; and 2 Corinthians 1:1-4:17.88 Our information about this stage in the life of S151a is insufficient to know how long it lasted. It is likely that Si51a was no longer in al-Yabrūdī's possession when these segments were lost. Indeed, given how active al-Yabrūdī was in collating manuscripts, he would never have left it defective.

\subsection{The Restored Si51a}

S151a's restoration process was a complicated one that involved several individuals. It is possible that this procedure took place in a workshop since we know it involved more than one scribe and at least a binder. As we shall see, it also required the gathering of two manuscripts together. Thus, I use the term "restorers" when referring to those responsible for this process, rather than speaking of a specific person.

\footnotetext{
87 He might have meant tahtammu bi-al-dunya "she cares for the world," because the phrase "for the world" is not found in Greek manuscript B.

88 Staal, Mt. Sinai Arabic Codex 151, I. Pauline Epistles [Translation], i.
} 
Generally, restoring a manuscript was a difficult and expensive process. In Mediterranean Society, Shelomo Goitein narrates an incident when the Jewish community in thirteenth century Egypt attempted to restore the damaged leaves of a codex but some experts refused, stating that, "the resurrection of the dead is more difficult than bringing a human being into existence." ${ }^{89}$ Thus, the community was forced to bring in another restorer and pay him substantially to restore the codex. In the case of $S_{151 a}$, the restoration took place earlier, probably around the twelfth century, and we can assume that it, too, was an expensive operation. The process entailed three steps that can be detailed as follows:

\subsubsection{Substitution of the Damaged Folios}

The restorers replaced the damaged folios with new ones. Examining these substituted folios reveals many things about the restoration. There is strong evidence that the restorers had no access to the original text of S151a. The missing parts involve the beginnings of Romans and 2 Corinthians. As mentioned above, each epistle features an introduction that precedes its text. The two introductions in the case of Romans and 2 Corinthians should have existed in the substituted folios, but they do not. We know, however, that these introductions existed earlier in S151a since we can read them today in one of its witnesses, namely $\mathrm{F}_{532}$. F532 was in all likelihood copied after the restoration process of S151a, which implies that the exemplar F 532 was copied from S151a before the latter lost these folios. Moreover, the annotations of the original text in S151a do not exist in the substituted folios, only in the biblical text. This means that the restorers had no access to the original leaves or to other copies of S151a because they were completely destroyed. An indication that the restoration took place after al-Yabrūdi's time is the absence of any variant readings, comments, or colophons by him on the substituted folios. Moreover, the layout of the substituted folios differs greatly from those of the original text [Figure 8 and cf. Figure 2]. Since only the biblical text is written in these folios, the margins are regular. Furthermore, the handwriting is completely different from that of the original text. It is closer to nash, curvy with more diacritics and a few vocalization marks.

There is also textual evidence to support the fact that the restorers did not have the original text and, moreover, that it did not appear to matter if the texts in one manuscript did not match each other. To demonstrate this, I take two sample verses from the substituted folios of S151a (Romans and 1Corinthians)

89 Shelomo D. Goitein, A Mediterranean Society: The Jewish Communities of the Arab World as Portrayed in the Documents of the Cairo Geniza, vol. II, The Community (Berkeley, CA: University of California Press, 200o), 239. 
and compare them to the original text of S151a kept in the manuscript-witnesses that were copied from it before these folios were lost.

(3) Romans 1:8

S151a (f. 2v): اني اول شي يا اخوه فاني اشكر الاهي الاب بربنا السوع المسيح من اجل جماعتكم لان امانتك قد انتشرت في بميع البشر

"Verily, I first of all, brethren, thank my God the Father (in) our Lord Jesus Christ because of all of you, because your faithfulness is spread about (abroad) among all mankind."90

MG2 (f. 1v): اما بعد فاني اولا اشكر لالهي بيسوع المسيح عن جميعكم من اجل ان ايمانكم قد ذاع في العالم باسره

B162 (f. 163r): اما بعد فاني اولى اشكر لالا هي إيوع المسيح عن جميعكم من اجل ايمانكم قد ذاع في العالم باسره

"Then, I, first, thank my God in Jesus Christ for all of you because your faith is spread about $\left(\underline{d} \bar{a}^{c} a\right)$ in the whole world (al-'alam bi-asrihi)."

F532 (f. 7v): اما بعد فاني اول كل شي اني شاكر الله بايسوع المسيح عن جميعكم لان ايمانكم قد شاع في كل العالم

"Then, I, first of all, thanking my God in Jesus Christ for all of you because your faith is spread about $\left(\check{s}^{c} a\right)$ in the whole world (kull al-'âlam)."

(4) 1 Corinthians $7: 17$

S151a (f. 47v): كل انسان منكم يا إخوة فليرضا بما قسم الله وكل انسان لما دعاه الله فليسلك مهذا الأمر

"Brethren, let every person of you be satisfied with what God has allotted. As God has called every person, let him walk in that matter."91

MG2: lacuna

90 Staal, Mt. Sinai Arabic Codex 151, I. Pauline Epistles [Translation], 1.

91 Ibid., 62. 
B162 (f. 186r): ولكن انسانا انسانا كما قسم الرب والانسان كما دعاه الله كذلك فليسر "But each man as the Lord has allotted, and a man as God has invited him, let him walk."

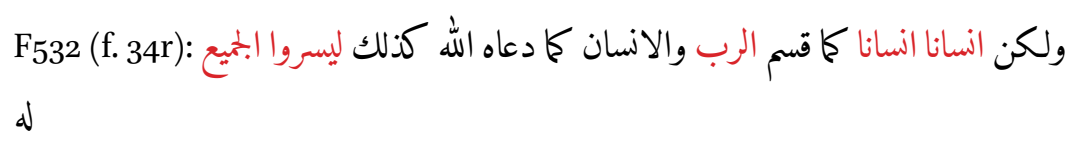

"But each man as the Lord has allotted to him, and a man as God has invited him, let everyone walk."

This comparison reveals that the text of S151a's substituted folios considerably differs from the original text, attested by its witnesses. While the meaning is equivalent in all the manuscripts in example (3), the text of S151a inserts some words that do not exist in the text of the other manuscripts, i.e. "Brethren," "the Father," and "our Lord", none of which originate in any Vorlage either. S151a employs the verb intašara, yet MG2 and B162 use $\underline{d} \bar{a}^{c} a$, and $\mathrm{F}_{532}$ employs $\check{s}^{\prime} \bar{a}^{c} a$. The text in the other manuscripts begins with ammā ba'd, which has no origin in any source text but is a common idiom in Arabic letters when transferring from the introduction of a letter to its subject. ${ }^{92}$

The fourth example is even clearer in showing the distinction. S151a is more interpretive in this verse by adding ya ihwa, "o brothers" and a verb yard̄a, "let him be satisfied." Furthermore, it harmonizes the verse, using allāh twice, while the other versions show more commitment to Syriac, using al-rabb, "Lord" in the first instance and allāh in the second. The method of expressing "each person" is also different. S151 follows the Arabic language requirements that, unlike Syriac, do not allow for repetition, while the other witnesses literally translate

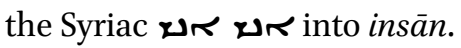

From this textual and codicological evidence of S151a and its witnesses we can posit two important things. First, it cannot be that all of these manuscripts were directly copied from S151a. MG2 might have been, but there is no concrete evidence to support this. Indeed, two of the manuscripts were copied in the thirteenth century, yet they still bear the original text of S151a before a new text intervened and replaced it (ca. twelfth century). This implies that they were copies of pre-twelfth century copies of S151a. Second, it is clear that S151a was

92 We notice that although the text in the three witnesses is very similar, as mentioned above, F532 deviates from the other two manuscripts at some points. For instance, it has the participle shākir, as opposed to the verb ashkur used in MG2 and B162, and while the latter manuscripts read fì al-'ālam bi-asrihi, $\mathrm{F}_{532}$ reads $f \grave{\imath}$ kull al-'álam. 
copied more than once and that a number of these copies did not survive. We know this because the earliest manuscript-witness copied only the biblical text while one of the later manuscripts copied the introductions.

The question becomes, which text did the restorers use? Actually, the substituted text does not match any version of the Pauline Epistles in Arabic that I know of. ${ }^{93}$ Thus, it is probable that this version was translated specifically for the restoration of $\mathrm{S}_{151 \mathrm{a}}$, or that all the other witnesses to it are lost. On examining the Vorlage of the substituted text, taking into account the Syriac traces noticed in the aforementioned examples, we discover more of a tendency to a Greek source text, as in the following examples:

(5) Romans 1:14 (f. 2v) is rendered فكذلك يجب على "so I am obliged to," as in the

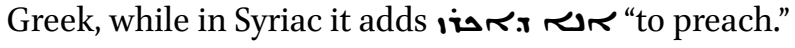

(6) Although 1 Corinthians 7:3 (f. 47r) is missing a part, it shows a trace of Greek influence in the word al-karāma. This word exists only in Greek manuscript 76 (fourteenth century).

(7) ${ }_{1}$ Corinthians 7:5 (f. 47r) does not contain the Byzantine Greek or Syriac addition al-șawm, "fasting," but reads as in the Alexandrian Greek al-șalät, "prayer" only. It should be noted that a Syriac trace is also detected in 7:14, which reads "their children", unlike the Greek, which reads "your children."

(8) Syriac adds many pronouns that do not exist in Greek, or in the substituted folios of S151a, as in verse 4 (f. 47r): "his woman/wife" in Syriac but "the woman" in Greek and S151a. ${ }^{94}$

Another feature of the substituted text is its free renderings; for instance, the addition of al-ibn in Romans 1:7, and the other words mentioned earlier in Romans 1:8 (f. 2v) that do not belong to the Vorlage. ${ }^{95}$ These free renderings are detected in particular in the substituted text of 2 Corinthians:

93 My inventory of the Pauline Epistles in Arabic manuscripts reveals about fourteen versions that come from different Vorlagen (Greek, Syriac, Coptic, and Latin). See Vevian Zaki, "The Pauline Epistles in Arabic: Manuscripts, Versions, and Text Transmission." (PhD diss., Ludwig-Maximilians-Universität, 2019), 376-420.

94 The text of S151a reveals extensions and readings that are not common in Greek or Syriac, i.e. v. 6, which should read "not a commandment" but in S151a reads: ليس أعزم عليك "... I do not force you."

Romans 1:7 reads: النعمه تكون معكم والسلام من الله الاب والرب إسوع المسيح الابن, “Grace be 
(9) 2 Corinthians 1:8b-9a (f. 72r-v)

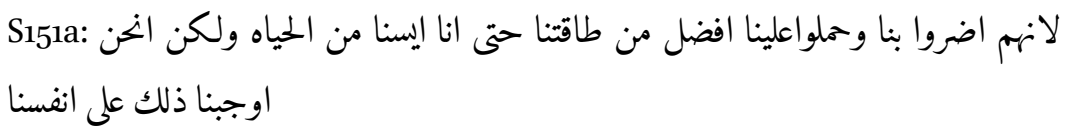

"Because they harmed us and burdened us with more than we could bear, so we really despaired of life. Yet, have we forced this upon ourselves?"

To understand the free rendering in this verse, compare it to the English Standard Version that is translated from the Greek: ${ }^{96}$ "For we were so utterly burdened beyond our strength that we despaired of life itself. Indeed, we felt that we had received the sentence of death."

The paraphrasing of the meaning with the addition of some interpretation is palpable in this passage. ${ }^{97}$

Since the restorers provided only the biblical text, they did not need to prepare quaternion quires as in the original quires. Instead, they substituted the exact number of the required folios according to the length of the substituted text. Thus, they inserted two folios for the text of Romans and two bifolia for the missing text in each of 1 and 2 Corinthians.

\subsubsection{Another Manuscript ( $\left.\mathrm{S}_{1516}\right)$}

At this point in S151a's history, another manuscript appears: S151b. This was a separate manuscript containing the Acts of the Apostles and the seven Catholic Epistles, both taken as one book and divided into 32 chapters, as was the habit in the Syriac tradition. Although the text of $\mathrm{S}_{15} \mathrm{~b}$ is penned by the same hand as S151a (Bišr ibn al-Sirrī), it was probably written on a separate occasion. The mise-en-page in Acts and the Catholic Epistles is slightly different from that in S151a. The biblical text is no longer written in shorter lines, but is almost equal in length to the annotations. In general, the text is also denser and smaller in Acts and the Catholic Epistles, and the annotations are, to an extent, much

with you and peace from God the Father, and the Lord Jesus Christ the Son." Moreover, Romans 1:9 reads: بشهد لي الله الاب الذي اخدمه بروحي في بشراي, "God the Father testifies to me, whom I serve with" my spirit in my Gospel." It ad̈ds al-ab and reads "my Gospel" instead of "the Gospel of his Son."

96 English Standard Version Bible with Apocrypha (New York: Oxford University Press, 2009).

97 The original text of S151a represented in the witnesses is closer to the Vorlage. For example: B162: انا جهدنا جهدا عظيما اكثر من طاقتنا حتى كانت حياتنا قد كادت وجزمنا الموت على انفسنا تضمحل

"We were greatly burdened beyond our energy such that our life was close to vanishing, and we felt the confirmation of death." 
shorter than those of the Pauline Epistles. Moreover, whole parts of the text have no annotations at all, such as 2 Peter, 2 and 3 John, and Jude. It seems that the reason for this can be found in the Syriac origin of the text that the translator used and the fact that these epistles entered the Syriac Canon later than the other Catholic Epistles. ${ }^{98}$ For the same reason, 1 John is probably inserted into S151b between James and 1 Peter. Several passages in Acts of the Apostles are also without annotations, such as ff. 210 (Acts 11:2-19) and 214 (Acts 13:1343).

In general, it seems that the scribe was more careful about conserving space in the case of Acts and the Catholic Epistles than in the case of the Pauline Epistles. Moreover, the original quire numeration in Greek does not exist in $\mathrm{S}_{15} 1 \mathrm{~b} ;{ }^{99}$ moreover, there is no cross sign or signs at the ends of the quires. With respect to the margins, they show less marks of an "active life." For instance, it seems that $S_{15} 1 \mathrm{~b}$ never reached al-Yabrūdī's possession, as there are no colophons or variant readings detected over the original text in his hands. A few notes are observed in S151b's margins, one being the lectionary rubrics that will be discussed below, in addition to three comments on the text written in red. ${ }^{100}$ This fact, in addition to the slightly different layout and density of the text in Acts and the Catholic Epistles compared to the Pauline Epistles as well as the absence of the Greek quire numbers from S151b, highlights that both S151a and S151b were independent manuscripts before they came together.

To the best of my knowledge, no one has ever examined the text of S151b, and it is beyond the scope of this paper to do so. Since, thus far, there have been no comprehensive studies of the Arabic text of Acts of the Apostles and the Catholic Epistles in Arabic, it is not possible to compare the substituted text of $S_{151} \mathrm{~b}$ with any other text or to know whether it is the original text of $S_{151} b$ or not. Furthermore, little is known about S151b's history due to the absence of any colophons or possession notes in it. ${ }^{101}$

98 See Jeffrey S. Siker, The Canonical Status of the Catholic Epistles in the Syriac New Testament (Oxford: Clarendon Press, 1987); and Bruce M. Metzger, The Canon of the New Testament: Its Origin, Development, and Significance, Reprinted ed. (Oxford: Clarendon Press, 1997), 218-223.

99 I owe this observation to Prof. Ronny Vollandt, who pointed out to me the absence of the Greek quire marks in S151b. Brock also made this observation in his article, "A Neglected Witness to the East Syriac New Testament Commentary Tradition," 207 (n. 9).

100 These comments are extant in ff. 205v, 207r, and 208r.

101 Staal takes the fact that the scribe of the substituted folios used less "Islamic terminology" such as the Islamic basmala as proof that the substitution happened at a later time, after the Crusades. See Staal, Mt. Sinai Arabic Codex 151, I. Pauline Epistles [Translation], v. 
Mention should be made here of Blau's argument again: in later manuscripts, it was not unusual to find colophons in the middle of a manuscript and not at its end. One example is B162, a witness of S151a, whose colophon is placed after the Gospels. ${ }^{102}$ The reason for this might be the vulnerability of the last folios and their susceptibility to destruction. This common vulnerability might have invited scribes to take precautions and write their colophons in the middle. However, in the case of Ms Sinai, Ar. 151, a combination of two previously separate manuscripts, Blau's argument is partially true but for different reasons.

Essentially, the lack of the original quire numeration (in Greek letters) after the Pauline Epistles, in addition to the slightly changed layout and different marginalia, confirms Blau's doubts that the date in the colophon of Bišr ibn alSirri does not refer to the whole manuscript but only the Pauline Epistles. While the entire manuscript was written by the same scribe, the Pauline Epistles were written separately from the Acts-Catholic Epistles part. Perhaps this segment also had its own colophon which was later lost (along with the last folio). There is no reason, then, to suspect the date of S151a as the earliest dated manuscript of the Arabic Bible. The exact date of $\mathrm{S}_{15} \mathrm{~b}$ cannot be affirmed, and it might be before or after S151a. It is expected, however, to be in the lifespan of Ibn al-Sirrī and not far from the date of $867 \mathrm{CE}$.

\subsubsection{S151a and S151b in the Hands of One Owner}

Before describing how S151a and S151b were combined into one volume, we must address the question of when the two manuscripts reached the hands of the same owner. We mentioned before that it is unlikely that al-Yabrūdī had access to $S_{15}$ b since his fingerprints are completely absent from it. Their paths crossed later, most likely in a community such as a church or monastery. The reason behind this suggestion is that the only common activity we find on the margins of both S151a and S151b is liturgical marks, namely rubrics of different readings over some passages. It should be noted that the substituted folios do not feature these signs, which means they survived separately for a while in this community. They may have lost some of their folios as a result of their frequent use in liturgy. One might consider that these liturgical rubrics go back

102 Another example is MS Leiden, UL, Or. 217. While the end of all the Gospels and epistles contain a short prayer by the scribe, its only colophon (f. 127r), which determines the year of transcription (1059 AM/1342 CE), comes after the Gospels. See P. Voorhoeve, Handlist of Arabic Manuscripts in the Library of the University of Leiden and Other Collections in The Netherlands, Codices Manuscripti 7 (Leiden: Bibliotheca Universitatis, 1957), 5 o. 
to the time after Ibn al-Sirrī had composed the two manuscripts. However, it is more likely that liturgy was a stage that followed, rather than preceded alYabrūdī. An indication for this is the Arabic script of the rubrics, which is nash and missing the sharp angles that distinguish the earlier scripts. The script was probably written in a period close to the process of restoring the manuscript (twelfth century).

The liturgical phase is a new skopos or function in the life of both manuscripts, especially S15ıa. Bišr ibn al-Sirrī combined the biblical text, divided into chapters, along with introductions, annotations, and glosses, but he made no reference to any ecclesiastical calendars. Thus, the liturgical role was not planned from S151a's inception. Al-Yabrūdī's activities in its marginalia were related to collations and corrections and included no liturgical rubrics or marks. Thus, we can conclude that S151a functioned hitherto as a study Bible.

Two sets of liturgical lectionary rubrics in Arabic and Greek survive in the margins of S $151 \mathrm{a}$ and S $151 \mathrm{~b}$ [Figure 2]. The Arabic rubrics were added in a thick, black, chaotic handwriting in the side margins throughout both of S151a and S151b. The handwriting is cursive, inconsistently dotted, and belongs to the eleventh-twelfth centuries, in my view. There are occasionally marks indicating the reading ending: الم ها هن "to this point." Most of the lectionary commemorates Sundays and festal occasions. ${ }^{103}$ Their number descends from thirty rubrics in the Pauline Epistles, thirteen rubrics in the Catholic Epistles, and finally eight rubrics in the Acts of the Apostles. Brock connects them with the Greek-Orthodox Church; however, they do not belong to the lectionary of Constantinople or that of Jerusalem. ${ }^{104}$ For example, the rubric that precedes Philippians 2:6-11 reads:

103 Some examples of the rubrics in Romans and Ephesians are:

Romans 5:1 Reading of the Sunday after Pentecost;

Romans 5:6 To be read in the [evening] of Cross Friday;

Romans 6:1 To be read for the third Sunday, and for Sanctification of Water;

Romans 6:3 To be read for the fourth Sunday of Pentecost;

Romans 8:2 To be read for the fifth Sunday of the Pentecost;

Romans 8:28 To be read in the Feasts of the Martyrs;

Ephesians 3:14 To be read for the eleventh Sunday of the Pentecost;

Ephesians 4:1 To be read for the twelfth Sunday of the Pentecost;

Ephesians 4:8 To be read for the Martyrs and the [Heads?];

Ephesians 4:17 To be read for the thirteenth Sunday of the Pentecost.

104 For more details on the Jerusalemite and Constantinople lectionaries in the manuscripts of the Pauline Epistles in Arabic, see Zaki, "The Textual History of the Arabic Pauline Epistles," 400-404. 


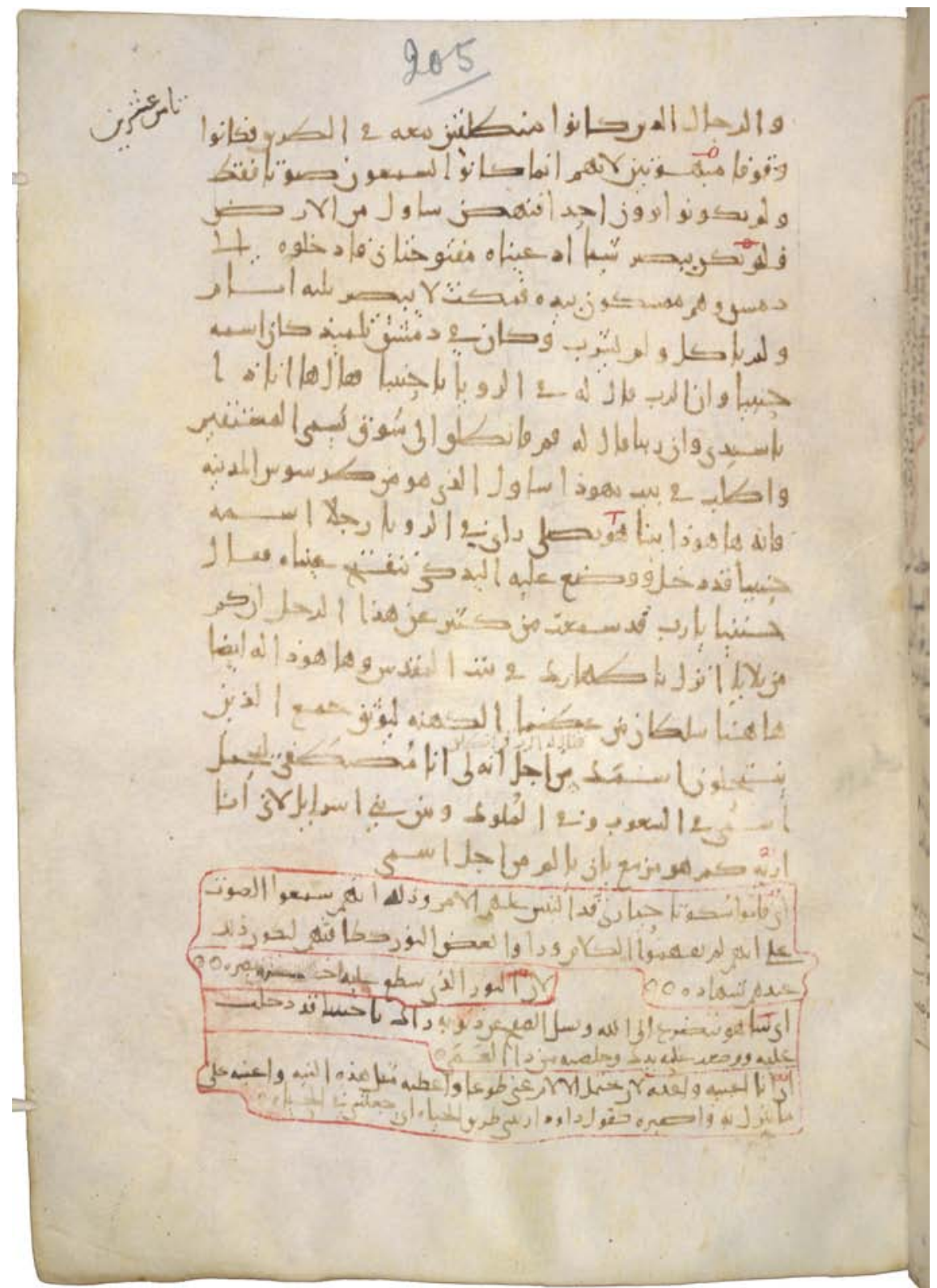

FIGURE 7 The original layout of $\mathrm{S}_{15} 1 \mathrm{~b}(\mathrm{f} .205 \mathrm{r})$

PHOTOGRAPH COURTESY OF SAINT CATHERINE'S MONASTERY, SINAI, EGYPT. 
S151 (f. 117r): قربان لتجلي المسيح (طوربابور) ويقرا ايضا عسى يوم بمعة الصلبوت "Offering for the transfiguration of Christ, and to be read"also on the eve of Cross Friday"

يقرافي الاحد العاشر:Jerusalem lectionary in Ms British Library, Or. 8612 (f. 6v) "To be read on the tenth Sunday [of Pentecost?]"

Constantinople Lectionary in MS Sinai, Ar. 16o (f. 173r): يقرا لنياحة سيدتنا ميمريم في الخامس عشر من اب

"To be read for the death of our lady Mar. Maryam, on the fifteenth of August"

The Greek rubrics exist in the upper margins of select folios where there are Arabic rubrics, but they never exist in folios alone. The majority exists in the Pauline Epistles (26 rubrics), and only once in each of the Catholic Epistles and the book of Acts. The fact that they are written in Greek suggests that this liturgy belongs to the Melkite tradition. Many Greek words are tangled and hard to decipher; nevertheless, $\alpha \nu \alpha \sigma \tau \dot{\sigma} \sigma \mu o l$, "Resurrection," is a repeated word in many of these rubrics. This implies that most of these readings are related to the Easter cycle. Additionally, most of the readings have an incipit that refers to the beginning of the reading. For example, Romans 5:1 (f. 1ov) reads: $\beta^{\prime} \alpha \nu \alpha \gamma \nu \omega-$

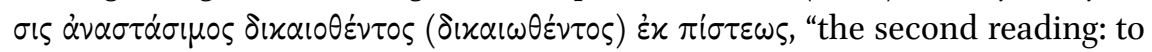
be read for Easter ... (Since we are justified by faith)." ${ }^{105}$ In contrast, the Arabic rubric in the same folio is related to Pentecost and reads: "Reading of the third Sunday after Pentecost."

The Arabic and Greek rubrics represent different calendars. Study of Arabic Liturgy is still in its infancy, and we do not have enough material with which to compare S151's rubrics. Comparing these Arabic and Greek rubrics to Syriac and Greek lectionaries available in Thesaurus Antiquorum Lectionariorum Ecclesiae Synagogaeque (ThALES) leads us nowhere. ${ }^{106}$ Thus, the exact association of the rubrics remains an open question. Moreover, there is no evidence about which set of rubrics was written first. Were the rubrics in the Greek language written

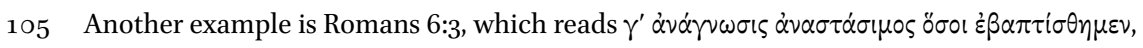
"For reading in the Easter ... (we, who were baptized)."

106 ThALES is a database for lectionaries of different traditions in various languages (Greek, Syriac, Latin, Hebrew, Arabic, etc.) extracted mainly from manuscripts. For more details, see http://www.lectionary.eu/content/contents-thales. 
in St Catherine's Monastery, S151's current home? There is no definite answer to this question either. If the assumption is correct, this would mean that $\mathrm{S}_{151}$, which was made in Damascus in the ninth century, reached its final destination in the eleventh/twelfth centuries, and has remained there ever since. This also indicates that both the damage and the restoration process must have happened in this monastery.

\subsubsection{Substitution of the Removed Folios of S $151 b$}

S151b suffered the loss of several folios from its initial pages (Acts 1:1-5:38a) and one at the end (Jude 13-24). We can observe that S151b was part of the same restoration process involving S151a. The same scribe substituted the text of the lost folios in Acts 1:1-5:38a in eight new folios (four bifolia) that constitute an individual codicological unit, as is the case in S151a. A different scribe may have written the text of the last substituted folio of the manuscript (the Epistle of Jude). In the substituted text of S151b, the scribe missed a number of words or phrases and supplied them in the margins along with explanations relating to a few words.

\subsubsection{Binding the Two Manuscripts in One Volume}

After substituting the removed folios from both $\mathrm{S}_{15} 1 \mathrm{a}$ and $\mathrm{S}_{15} \mathrm{~b}$, the restorers bound the two manuscripts together. They seemingly made new quire numerations throughout the whole manuscript (Pauline Epistles+ Acts+ Catholic Epistles) using Arabic numbers, written in letters such as 'āšira, ḥādì 'ašr, etc. The small prayer in the empty folios between S151a and S151b on f. 187v most likely belongs to the restoration process. It reads:

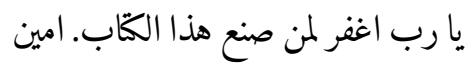

Lord, forgive the one who made this book. Amen.

The utilization of the word șana' $a$ is unique in that it does not refer to the action of copying a text, but rather to making a book, probably the binding. ${ }^{107}$ From this moment on, Ms Sinai, Ar. 151 came into existence.

107 Staal believed that the main reason for wasting a whole folio on writing this prayer was to confirm the separation between the text of the Pauline Epistles and the text of the Acts and Catholic Epistles. The reason was his observation that the Pauline Epistles form one textual unit that is divided into 55 chapters, while the Catholic Epistles and Acts of the Apostles represent together another textual unit that is divided into 32 chapters. See Staal, “Codex Sinai Arabic ${ }_{151}$ Pauline Epistle (Part I)," 12. 
The two manuscripts were sewn together at the spine using thick black thread [Figure 9] that is different from the greyish thread used internally to sew each quire to its preceding and following quire. The boards are attached to the quires using the Byzantine system and thick greyish threads [Figure 10].

There are no signs of activity for restored $S_{151}$ once it had become a whole manuscript. It seems that it was quietly preserved for centuries until the year $1870 \mathrm{CE}$ when the head of the Russian Spiritual Ministry in Jerusalem visited the Monastery in Sinai to prepare a catalogue of the Library. One of his assistants read through $\mathrm{S}_{15} 1$ and wrote a note mentioning:

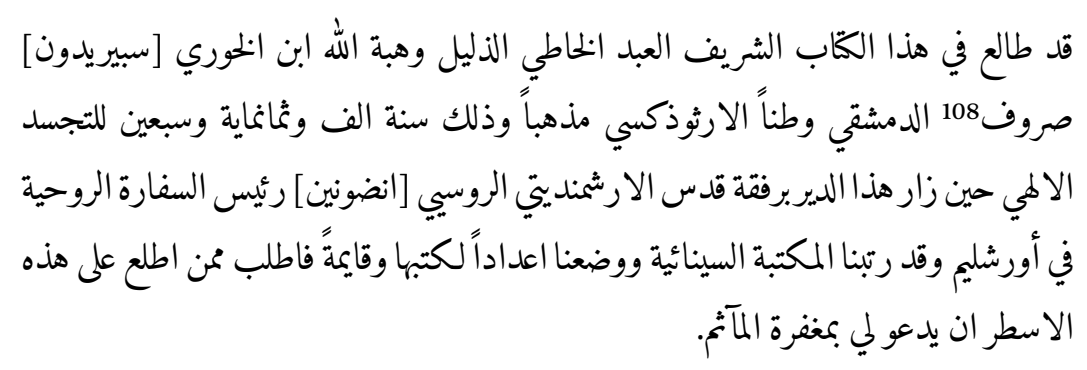

The despised slave, the sinner Wahbat Allāh the son of the priest Sbīīdūn Șarrūf, the Damascene by home-land, the Orthodox by religion, has inspected this noble book. This was in the year one thousand eight hundred and seventy after the divine incarnation (A.D.), when he visited this monastery in the company of the holy Russian Archimandrite Antonius, the head of the spiritual embassy in Jerusalem. We have arranged the Sinai Library. We have numbered its books and made a catalogue. I request from whoever reads these lines to pray for me for the forgiveness of my sins. ${ }^{109}$

108 He is known as Wahbat Allāh Șarrūf, who published a number of books through the Greek Orthodox Church using the Holy Sepulchre Press in Jerusalem, including the Gospels, and the Apostolos, which he collated against the Greek, in addition to the Hours Prayers, and other books. See for example, Wahbat Allāh Șarūf, Al-Inğĭl al-Ilāhī al-Šarīf (The Honored Gospel) (Jerusalem: The Holy Sepulchre Press, n.d.).

109 Staal, Mt. Sinai Arabic Codex 151, I. Pauline Epistles [Edition], vi. 


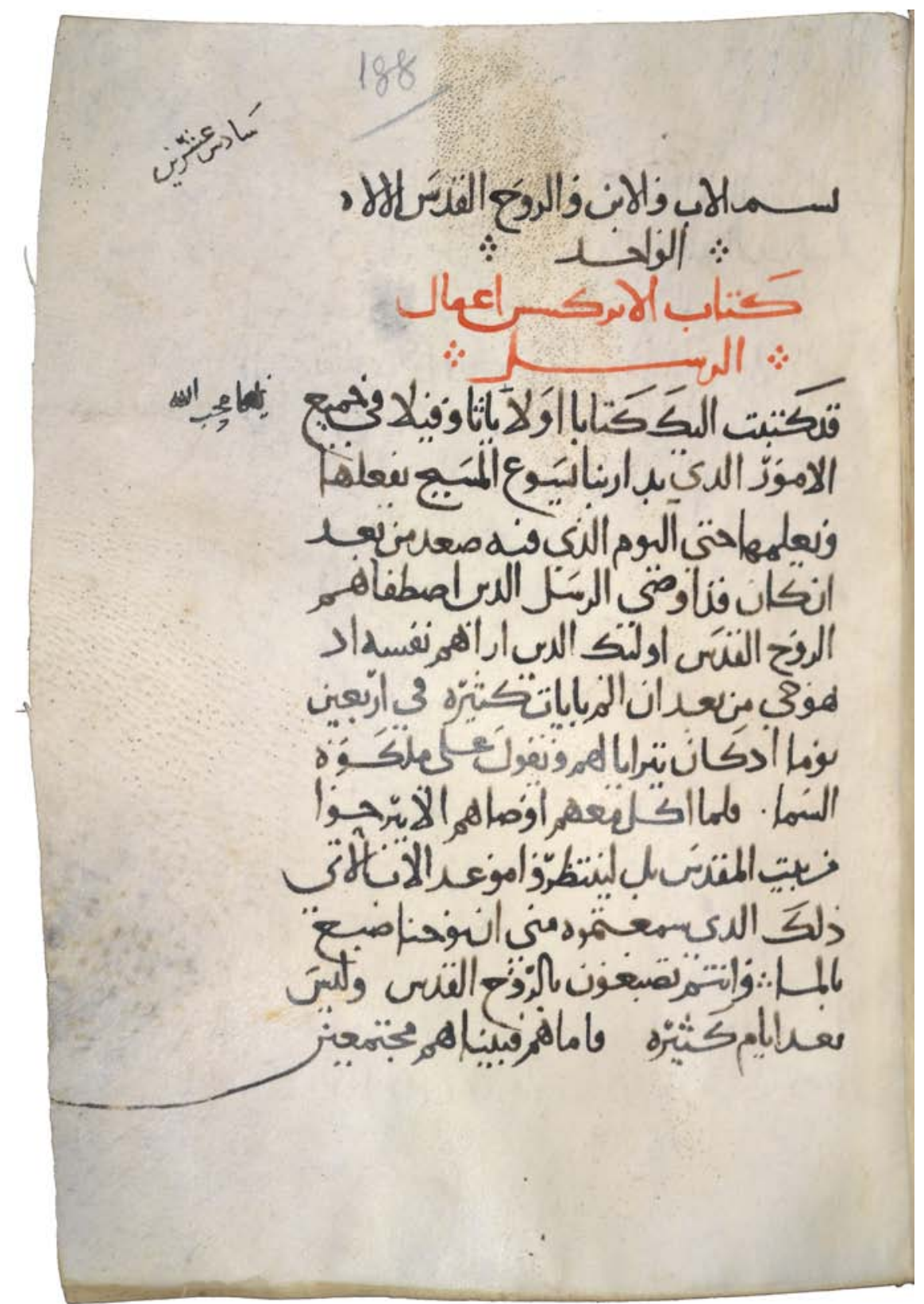

FIGURE 8 A substituted folio in S151b (f. 188r)

PHOTOGRAPH COURTESY OF SAINT CATHERINE'S MONASTERY, SINAI, EGYPT. 


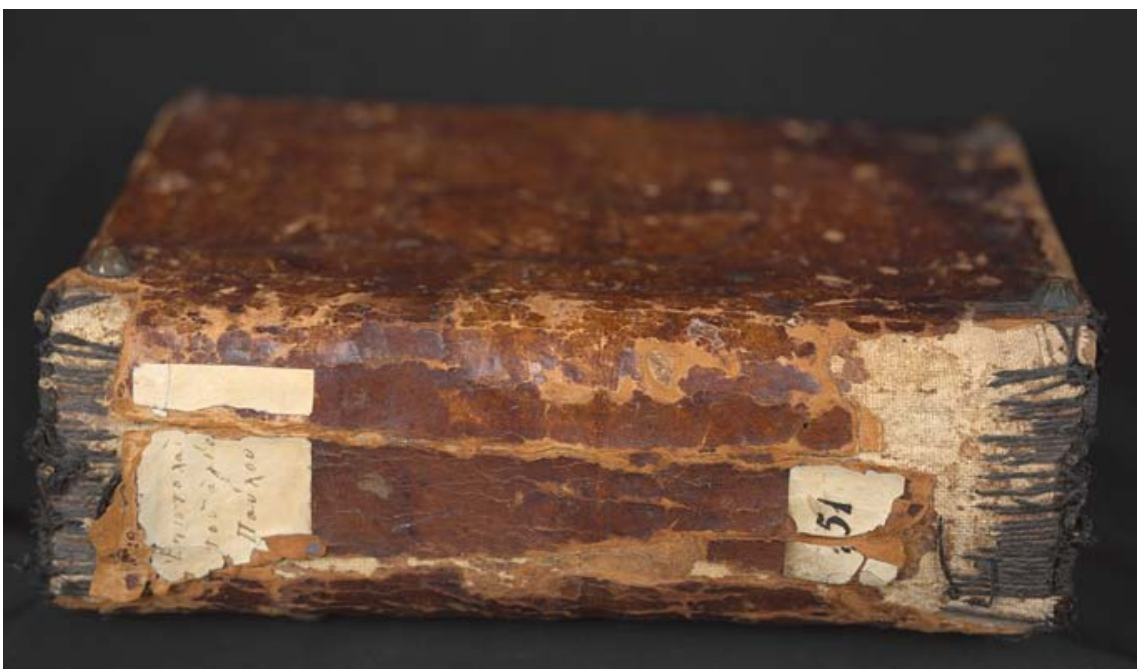

FIGURE 9 The black thread of the binding of the two manuscripts, together forming S151 PHOTOGRAPH COURTESY OF SAINT CATHERINE'S MONASTERY, SINAI, EGYPT.

In 1894, Margaret Gibson, published a catalogue of the Arabic collection in St Catherine's Monastery that was one of the precious outcomes of the multiple trips she made to Sinai with her sister Agnes Lewis. ${ }^{110}$ In this catalogue, S151 comes into view as an Arabic manuscript with a precise description of its contents but without any hints about its date or origin. ${ }^{111}$ Graf transmitted the information in his Geschichte and the manuscript remained hidden until the Library of the Congress started its digitization project in 1950. Aziz Atiya attracted the attention of his student Staal to this particular manuscript in 1955, and the latter has made it his life's work ever since. ${ }^{112}$

\section{4}

\section{Conclusion}

The life history of Ms Sinai, Ar. 151 is more complicated than it seems at first glance: on the codicological level, it began as two manuscripts and ended as one. On the denominational level, its text bears witness to more than one

110 Janet Soskice, The Sisters of Sinai:How Two Lady Adventurers Discovered the Hidden Gospels (New York: Vintage, 2010).

111 Margaret Dunlop Gibson, Catalogue of the Arabic Mss. in the Convent of S. Catharine on Mount Sinai (London: C.J. Clay and Sons, 1894), 22.

112 Staal, "Codex Sinai Arabic ${ }_{51}$ Pauline Epistle (Part II)," viii. 


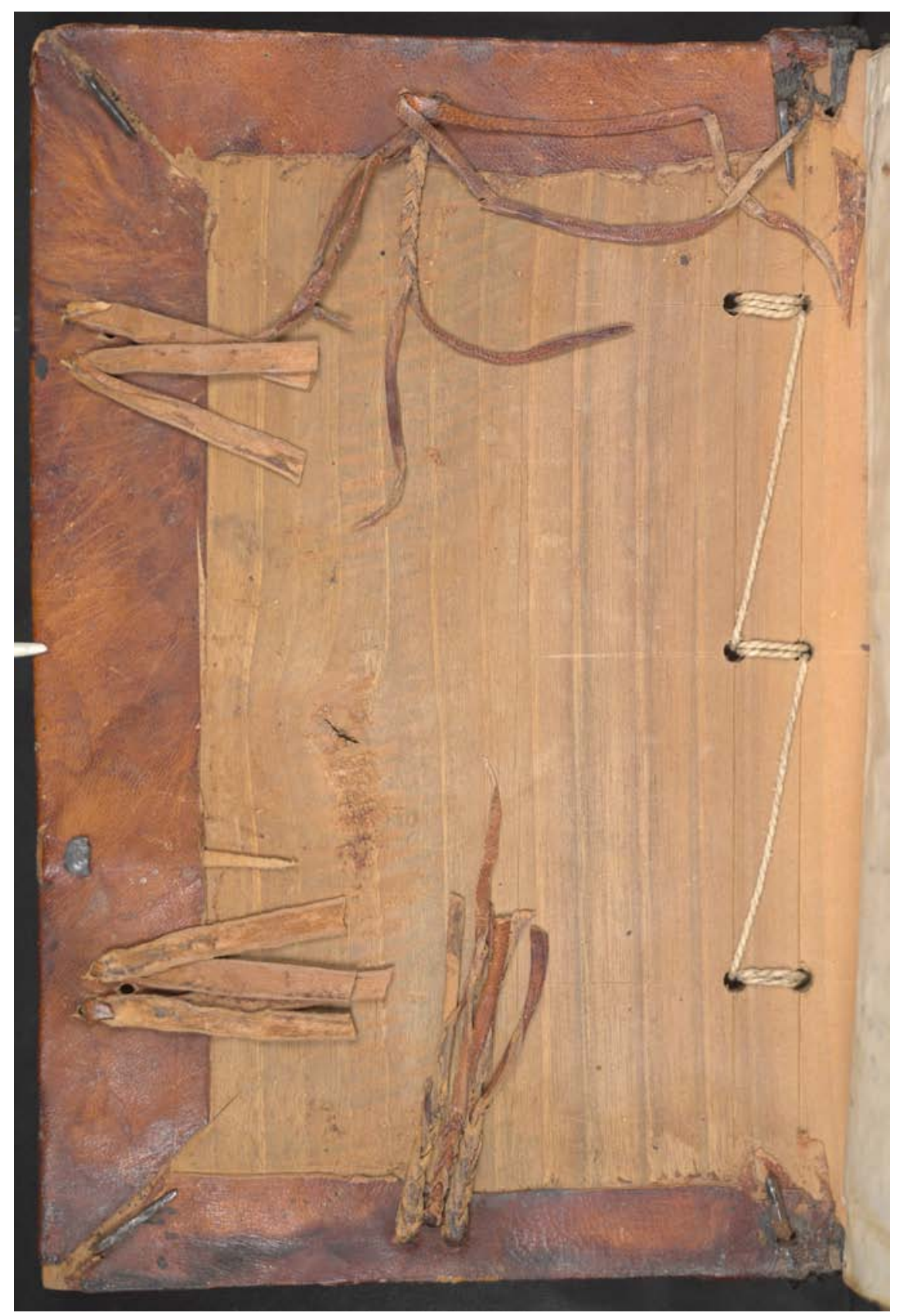

FIGURE 10 The Byzantine binding of the boarding of $\mathrm{S}_{15}$ PHOTOGRAPH COURTESY OF SAINT CATHERINE'S MONASTERY, SINAI, EGYPT. 
denomination; indeed, it survived and served in at least three different denominations. On the skopos level, it served as a study Bible, in liturgy, and, following its restoration, it appears to have been preserved as a valuable item without any signs of activity.

The hidden history of ms Sinai, Ar. 151 has been partially unfolded. Yet, in many ways, these unfolded parts expand and provoke many questions about: the circulation of the Arabic Bible across the denomination barriers; the different stages and persons involved in restoring a manuscript; the Arabic liturgy and its variation from the preceding Syriac and Greek liturgies, etc. Moreover, a critical edition of this text, employing all its newly discovered manuscriptwitnesses, is certainly needed for tracing the text's transmission history.

It would never have been possible to unfold these parts of this rich and long life without different aspects of the manuscript having been integrated. The examination of the Bible in Arabic is no longer an investigation of the biblical text alone, but rather a scrutiny of the whole manuscript.

\section{Acknowledgments}

I wrote this paper as part of my work in the DFG-funded project Biblia Arabica in Ludwig-Maximillians Universität in Munich. I am indebted to my advisor Prof. Ronny Vollandt, and my colleagues Nathan Gibson, Miriam L. Hjälm, and Peter Tarras for their valuable comments on it. I also appreciate the generous help of Fr. Justin, the librarian of St Catherine Monastery's Library and the permissions he gave me to examine the manuscripts in person and to add photos to this paper. Without his help this work would never have come to fruition.

\section{Bibliography}

\section{Sigla}

B162: Ms Berlin, Staatsbibliothek zu Berlin, Diez A Oct. 162

F532: Ms Florence, Biblioteca Medicea Laurenziana, Conv. Soppr. $53^{2}$

MG2: MS Sinai Ar. NF, parch. MG2

S151: MS Sinai, Ar. 151

\section{Manuscript Sources}

Ms Berlin, Staatsbibliothek zu Berlin, Diez A Oct. 162 [B162]

Ms Cairo, CM, Bible 94

Ms Florence, Biblioteca Medicea Laurenziana, Conv. Soppr. 532 [F532] 
MS Leiden, UL, Or. 217

MS London, BL, Or. $495^{\circ}$

MS London, BL, Or. 8612

Ms Oxford, Bodl. Arab. d. 19

Ms Paris, BnF, Ar. 1

Ms Sinai, Ar. 1

Ms Sinai, Ar. 2

Ms Sinai, Ar. 34

Ms Sinai, Ar. 35

Ms Sinai, Ar. 36

Ms Sinai, Ar. 73

MS Sinai, Ar. 151 [S151]

Ms Sinai, Ar. 154

Ms Sinai, Ar. 155

Ms Sinai, Ar. 159

Ms Sinai, Ar. 16o

MS Sinai, Ar. 168

Ms Sinai, Ar. 268

Ms Sinai, Ar. 400

Ms Sinai, Ar. 401

Ms Sinai Ar. NF, parch. MG2 [MG2]

Ms. Sinai Ar. NF, Parch. 14

Ms St Petersburg, NLR, A.N.S. 327

Ms Vatican, Ar. 13

Ms Vatican, Ar. 28

Ms Vatican, Gr. 2282

\section{Printed Sources}

Ahlwardt, W. Die Handschriften-Verzeichnisse der Königlichen Bibliothekzu Berlin. Vol. 9. Verzeichniss der Arabischen Handschriften 21. Berlin: A. Asher \& C., 1897.

Aland, Barbara, Kurt Aland, Bruce Manning Metzger, Johannes Karavidopoulos, and Carlo M. Martini, eds. Novum Testamentum Graece: Nestle-Aland. 28th revised ed. Stuttgart: Hendrickson, 2012.

Aland, Barbara, and Andreas Juckel, eds. Das Neue Testament in syrischer Überlieferung. Vol. II. Die Paulinischen Briefe/1 (Römer und 1. Korintherbrief). Arbeiten zur Neutestamentlichen Textforschung 14. Berlin: De Gruyter, 1991.

Aland, Barbara, and Andreas Juckel, eds. Das Neue Testament in syrischer Überlieferung. Vol. II. Die Paulinischen Briefe/2 (2. Korintherbrief, Galaterbrief, Epheserbrief, Philipperbrief und Kolosserbrief). Arbeiten zur Neutestamentlichen Textforschung 23. Berlin: De Gruyter, 1995 . 
Aland, Barbara, and Andreas Juckel, eds. Das Neue Testament in syrischer Überlieferung. Vol. II. Die Paulinischen Briefe/3 (1./2. Thessalonicherbrief, 1./2. Timotheusbrief, Titusbrief, Philemonbrief und Hebräerbrief). Arbeiten zur Neutestamentlichen Textforschung 32. Berlin: De Gruyter, 2002.

Atiya, Aziz Suryal. Catalogue Raisonné of the Mount Sinai Arabic Manuscripts: Complete Analytical Listing of the Arabic Collection Preserved in the Monastery of St. Catherine on Mt. Sinai. Translated by Joseph N. Youssef. Alexandria: Dār al-Macāifif, 1970.

Awad, Wadic. "Al-As'ad ibn al-'Assal, Introduzioni alla traduzione dei quattro Vangeli." Studia Orientalia Christiana Collectanea 39 (2006): 47-120.

Baum, Wilhelm, and Dietmar W. Winkler. The Church of the East: A Concise History. London: Routledge, 2010.

Benzelius, Henricus. Caroli Auriuillii Recensio Codicum Manuscriptorum. Uppsala: Litteris Edmannianis, 1802 .

Binggeli, André. "Les trois David, copistes arabes de Palestine aux 9e-1oe." In Manuscripta Graeca et Orientalia mélanges monastiques et patristiques en l'honneur de Paul Géhin, edited by Anne Boud'hors, André Binggeli, and Matthieu Cassin, 79-117. Orientallia Lovaniensia Analect 243. Leuven: Peeters, 2016.

Blau, Joshua. "Über einige Christlich-Arabische Manuskripte aus dem 9. und. 10. Jahrhundert." Le Muséon: Revue d'Études Orientales 75 (1962): 101-108.

Brock, Sebastian P. "A Neglected Witness to the East Syriac New Testament Commentary Tradition: Sinai Arabic MS 151." In Studies on the Christian Arabic Heritage, edited by Rifaat Ebied and Herman Teule, 205-215. Eastern Christian Studies 5. Leuven: Peeters, 2004.

Brock, Sebastian P. The Bible in the Syriac Tradition. Kottayam: St. Ephrem Ecumenical Research Institute, 1988.

Clarke, Kenneth W. Checklist of Manuscripts in St. Catherine's Monastery, Mount Sinai: Microfilmed for the Library of Congress, 1950. Washington, DC: Library of Congress, $195^{2}$.

D’Aiuto, Francesco. "La “scrittura mista" maiuscolo-minuscola d' area mediorientale." In Griechisch-byzantinische Handschriftenforschung: Traditionen, Entwicklungen, neue Wege, edited by Christian Brockmann, Daniel Deckers, Dieter Harlfinger, and Stefano Valento, 147-171. Berlin: De Gruyter, 2018.

Déroche, François. Islamic Codicology: An Introduction to the Study of Manuscripts in Arabic Script. Corr. ed. London: Al-Furqān Islamic Heritage Foundation, 2005.

Déroche, François. The Abbasid Tradition: Qur'ans of the 8th to the 1oth Centuries AD. London: Nour Foundation, 1992.

English Standard Version Bible with Apocrypha. New York: Oxford University Press, 2009.

Féghali, Paul. "Les épîtres de saint Paul dans une des premières traductions en arabe." Parole de l'Orient 30 (2005): 103-129. 
Frantsouzoff, Serge. "Les chiffres coptes dans les manuscrits arabes, chrétiens et musulmans." Parole de l'Orient 39 (2014): 259-273.

Gacek, Adam. The Arabic Manuscript Tradition: A Glossary of Technical Terms and Bibliography; Supplement. Leiden: Brill, 2008.

Gibson, Margaret Dunlop, ed. An Arabic Version of the Acts of the Apostles and the Seven Catholic Epistles from an Eighth or Ninth Century MS. in the Convent of St Catherine on Mount Sinai, with a Treatise on the Triune Nature of God, with Translation, from the Same Codex. Studia Sinaitica 7. London: C.J. Clay and Sons, 1899.

Gibson, Margaret Dunlop, ed. An Arabic Version of the Epistles of St Paul to the Romans, Corinthians, Galatians, with Part of the Epistle to the Ephesians from a Ninth Century MS. in the Convent of St Catharine on Mount Sinai. Studia Sinaitica 2. London: C.J. Clay and Sons, 1894.

Gibson, Margaret Dunlop, ed. Catalogue of the Arabic Mss. in the Convent of S. Catharine on Mount Sinai. London: C.J. Clay and Sons, 1894.

Gibson, Nathan, Miriam L. Hjälm, Peter Tarras, Ronny Vollandt, and Vevian Zaki. "The Bible in Arabic: An Update on the State of Research." In Between the Cross and the Crescent: Studies in Honor of Samir Khalil Samir, s.J. on the Occasion of His Eightieth Birthday, edited by Željko Paša, 57-84. Rome: Pontificium Institutum Studiorum Orientalium, 2018.

Goitein, Shelomo D. A Mediterranean Society: The Jewish Communities of the Arab World as Portrayed in the Documents of the Cairo Geniza. Revised ed. Vol. II, the Community. Berkeley, CA: University of California Press, 2000.

Graf, Georg. Geschichte der christlichen arabischen Literatur. Vol. I. Studi e Testi 118. Vatican: Biblioteca Apostolica Vaticana, 1944.

Graf, Georg. Geschichte der christlichen arabischen Literatur. Vol. II. Studi e Testi 133. Vatican: Biblioteca Apostolica Vaticana, 1947.

Gregory, Caspar René. Textkritik des Neuen Testamentes: Die Übersetzung-die Schriftsteller-Geschichte der Kritik. Vol. II. Leipzig: J.C. Hinrichs, 1902.

Griffith, Sidney H. "From Aramaic to Arabic: The Languages of the Monasteries of Palestine in the Byzantine and Early Islamic Periods." Dumbarton Oaks Papers $5^{1}$ (1997): $11-31$.

Griffith, Sidney H. "Greek into Arabic: Life and Letters in the Monasteries of Palestine in the Ninth Century: The Example of the 'Summa Theologiae Arabica." Byzantion 56 (1986): 117-138.

Griffith, Sidney H. The Bible in Arabic: The Scriptures of the "People of the Book" in the Language of Islam. Princeton: Princeton University Press, 2013.

Griffith, Sidney H. "The Gospel in Arabic: An Inquiry into Its Appearance in the First Abbasid Century." Oriens Christianus 69 (1985): 126-167.

Griffith, Sidney H. "The Monks of Palestine and the Growth of Chrisitan Literature in Arabic." Muslim World 78 (1988): 1-28. 
Harlfinger, Dieter. "Beispiele der Maiuscula Ogivalis Inclinata vom Sinai und aus Damaskus." In Alethes philia. Studi in onore di Giancarlo Prato, edited by M. D'Agostino, 461-477. Collectanea 23. Spoleto: Centro italiano di studi sull' alto medioevo, 2010.

Hjälm, Miriam L. Christian Arabic Versions of Daniel: A Comparative Study of Early $M$ ss and Translation Techniques in Mss Sinai Ar. 1 and 2. Biblia Arabica 4. Leiden: Brill, 2016.

Hjälm, Miriam L. "Paleographical Typology of Early Christian Arabic Scripts (ca. gth c.).” In Textual History of the Bible, edited by Armin Lange. III. Leiden: Brill, forthcoming.

Ibn Abī Ușaybi'a. 'Uyūn al-Anbā' fì Tabaqāt al-Ațibbāà (Best Accounts in the Classes of Physicians). Edited by E. Savage-Smith, S. Swain, G.J. van Gelder (Leiden: Brill, 2020).

Justin of Sinai, Hieromonk, and Jack Tanus. "Exploring a Ninth Century Sinai Palimpsest." Dumbarton Oak, 2010.

Kashouh, Hikmat. The Arabic Versions of the Gospels: The Manuscripts and Their Families. Berlin: De Gruyter, 2011.

Kawatoko, M. "On the Use of Coptic Numerals in Egypt in the 16th Century." Orient 28 (1992): $5^{8-74 . ~}$

Kerr, Robert M., and Thomas Milo, eds. Writings and Writing from Another World and Another Era: Investigations in Islamic Text and Script in Honour of Dr Januarius Justus Witkam Professor of Codicology and Paleography of the Islamic World at Leyden University. Cambridge: Archetype, 2014.

Lamoreaux, John C. "The Biography of Theodore Abū Qurrah Revisited." Dumbarton Oaks Papers 56 (2002): 25-40.

Lamoreaux, John C. “Theodore Abū Qurra." In Christian-Muslim Relations: A Bibliographical History, edited by David Thomas and Barbara Roggema, I, 6oo-900:253255. Leiden: Brill, 2009.

Martel-Thoumian, Bernadette. Les manuscrits arabes déposés à la Bibliothèque Medicea Laurenziana de Florence: Nouvelles acquisitions. Florence: Department of Languages, University of Florence, 1997.

Messiha, H., and Anne Boud'hors. "Les Chiffres Coptes." Le Monde Copte 24 (1994): 2528.

Metzger, Bruce M. The Canon of the New Testament: Its Origin, Development, and Significance. Reprinted ed. Oxford: Clarendon Press, 1997.

Monferrer-Sala, Juan Pedro. “Al-Yabrūdī." In Christian-Muslim Relations: A Bibliographical History, edited by David Thomas and Alexander Mallett, III, 1050-1200:127-129. Leiden: Brill, 2011.

Morozov, Dmitry A. "Aleksandrijsaja Èra v Lavre Sv. Savvy Osviash'ennogo [The Alexandrian Era at Mar Saba]." Kapterevskie Chtenija 11 (2013): 69-71. 
Morozov, Dmitry A. "K Datirovke Drevnejshej Arabskoj Rukopisi Evangelija [On the Dating of the Earliest Arabic Gospel Manuscript]." Kapterevskie Chtenija: Sbornik Statej 6 (2008): 19-23.

Nasrallah, Joseph. "Deux versions melchites partielles de la Bible du Ixe et du xe siècles." Oriens Christianus 64 (1980): 203-206.

Orsini, Pasquale. "La maiuscola ogivale inclinata. Contributo preliminare." Scripta 9 (2016): 89-116.

Perria, Lidia. "Scriture e codici di origine orientale (Palestina, Sinai) dal IX al XIII secolo. Rapporto preliminare." Rivista di Studi Bizantini e Neoellenici 36 (2000): 1933 .

Petermann, Julius H., ed. Pauli epistola ad Philemonem speciminis loco ad fidem versionum orientalium veterum una cum earum textu originaligraece. Berlin: Sumptibus C.G. Lůderitz, 1844 .

Pizzi, Italo. Index Codicum Manuscriptorum Orientalium qui in Bibliotheca MediceaLaurentiana Florentiae adservantur. Florence: Bibliotheca Medicea-Laurentiana Flor. adservantur, 1881.

Rauch, Christoph. "The Oriental Manuscripts and Albums of Heinrich Friedrich von Diez and the Perception of Persian Painting in His Time." In Julia Gonnella, Friederike Weis and Christoph Rauch, The Diez Albums. Contexts and Contents. Leiden: Brill, 2016. Islamic Manuscripts and Books, Volume 11, 74-117, 2016.

Samir, Samir Khalil. "Michel évêque melkite de Damas au ge siècle. A propos de Bišr ibn al-Sirrī" Orientalia Christiana Periodica 53 (1987): 439-441.

Șarrūf, Wahbat Allāh. Al-Injül al-Ilāhī al-Sharīf (The honored Gospel). Jerusalem: The Holy Sepulchre Press, n.d.

Siker, Jeffrey S. The Canonical Status of the Catholic Epistles in the Syriac New Testament. Oxford: Clarendon Press, 1987.

Soskice, Janet. The Sisters of Sinai: How Two Lady Adventurers Discovered the Hidden Gospels. New York: Vintage, 2010.

Staal, Harvey. "Codex Sinai Arabic ${ }_{15} 1$ Pauline Epistle (Part I)." PhD diss., University of Utah, 1969.

Staal, Harvey. “Codex Sinai Arabic ${ }_{15}$ Pauline Epistle (Part II).” PhD diss., University of Utah, 1969.

Staal, Harvey. Mt. Sinai Arabic Codex 151: Acts of the Apostles, Catholic Epistles [Edition]. Corpus Scriptorum Christianorum Orientalium 462. Leuven: Peeters, 1984.

Staal, Harvey. Mt. Sinai Arabic Codex 151: Acts of the Apostles, Catholic Epistles [Translation]. Corpus Scriptorum Christianorum Orientalium 463. Leuven: Peeters, 1984.

Staal, Harvey. Mt. Sinai Arabic Codex 151, I. Pauline Epistles [Edition]. Corpus Scriptorum Christianorum Orientalium 452. Leuven: Peeters, 1983.

Staal, Harvey. Mt. Sinai Arabic Codex 151, I. Pauline Epistles [Translation]. Corpus Scriptorum Christianorum Orientalium 453. Leuven: Peeters, 1983. 
Staal, Harvey. "Pauline Authorship of the Epistle to the Hebrews According to Mt Sinai Arabic Manuscript 151." Reformed Review 21 (1967): 51-53.

Stenij, Edvard. Die altarabische Übersetzung der Briefe an die Hebräer, an die Römer und an die Corinther. Aus einem in St. Petersburg befindlichen Codex Tischendorfs vom Jahre 892 n. Chr. Helsinki: Frenckellska Tryckeri, 1901.

Swanson, Mark N. "Some Considerations for the Dating of Fī Tațlì Allāh al-Wāhịid (Sin. Ar. 154) and al-Ǧāmi` Wuğūh al-Īmān (London, British Library Or. 4950)." Parole de l'Orient 18 (1993): 115-141.

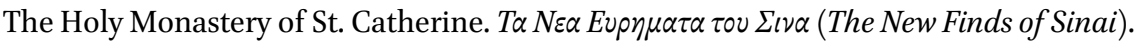
Athens: Ministry of Culture-Mount Sinai Foundation, 1999.

Treiger, Alexander. "From Theodore Abū Qurra to Abed Azrié: The Arabic Bible in Context." In Senses of Scripture, Treasures of Tradition: The Bible in Arabic among Jews, Christians and Muslims, edited by Miriam L. Hjälm, 9-57. Biblia Arabica 5. Leiden: Brill, 2017.

Treiger, Alexander. "New Evidence on the Arabic Versions of the Corpus Dionysiacum." Le Muséon 118, no. 3-4 (2005): 219-240.

Treiger, Alexander. "The Arabic Version of Pseudo-Dionysius the Areopagite's." Le Muséon 120 , no. 3-4 (2007): 365-393.

Vollandt, Ronny. Arabic Versions of the Pentateuch: A Comparative Study of Jewish, Christian, and Muslim Sources. Biblia Arabica 2. Leiden: Brill, 2015.

Vollandt, Ronny. "Flawed Biblical Translations into Arabic: A Copt and a Jew Study Saadiah's Tafsīr." In Heirs of the Apostles: Studies on Arabic Christianity in Honor of Sidney H. Griffith, edited by David Bertaina et al, 56-92. Arabic Christianity 1. Leiden: Brill, 2019.

Vollandt, Ronny. "From the Desks of a Coptic-Muslim Workshop: Paris, BnF, Ms Ar. 1 and the Large-Scale Production of Luxurious Arabic Bibles in Early Ottoman Cairo." In Patronage, Production, and Transmission of Texts in Medieval and Early Modern Jewish Cultures, edited by Esperana Alfonso and Jonathan Decter, 231-265. Turnhout: Brepols, 2014.

Vollandt, Ronny. "Making Quires Speak: An Analysis of Arabic Multi-Block Bibles and the Quest for a Canon." Intellectual History of the Islamicate World 4, no. 1-2 (2016): 170-209.

Vollandt, Ronny. "The Conundrum of Scriptural Plurality: The Arabic Bible, Polyglots, and Medieval Predecessors of Biblical Criticism." In The Text of the Hebrew Bible and Its Editions: Studies in Celebration of the Fifth Centennial of the Complutensian Polyglot, edited by Andrés Piquer Otero and Pablo A. Torijano Morales, I:56-85. Supplements to the Textual History of the Bible. Leiden: Brill, 2016.

Vollandt, Ronny. "The Status Quaestionis of Research on the Arabic Bible." In Studies in Semitic Linguistics and Manuscripts: A Liber Discipulorum in Honour of Professor Geoffrey Khan, edited by Nadia Vidro, Ronny Vollandt, Esther-Miriam Wagner, and 
Judith Olszowy-Schlanger, 442-467. Studia Semitica Upsaliensia 3o. Uppsala: Uppsala Universite, 2018.

Vollandt, Ronny, and Nathan Gibson, eds. Bibliography of the Arabic Bible: A Classified and Annotated History of Scholarship. Munich: Biblia-Arabica.com, 2017. http:// biblia-arabica.com/bibl.

Voorhoeve, P. Handlist of Arabic Manuscripts in the Library of the University of Leiden and Other Collections in The Netherlands. Codices Manuscripti 7. Leiden: Bibliotheca Universitatis, 1957.

Zaki, Vevian. "The Pauline Epistles in Arabic: Manuscripts, Versions, and Text Transmission." PhD diss., Ludwig-Maximilians-Universität, 2019.

Zaki, Vevian. "The Textual History of the Arabic Pauline Epistles: One Version, Three Recensions, Six Manuscripts." In Senses of Scripture, Treasures of Tradition: The Bible in Arabic among Jews, Christians and Muslims, edited by Miriam L. Hjälm, 392-424. Biblia Arabica 5. Leiden: Brill, 2017. 